\title{
EL ACCESO AL RECURSO DE CASACIÓN EN EL ORDEN CONTENCIOSO-ADMINISTRATIVO: UNA OPORTUNIDAD PERDIDA
}

\author{
María José Alonso Mas \\ Profesora Titular de Derecho Administrativo \\ Universidad de Valencia
}

\begin{abstract}
RESUMEN
El Tribunal Constitucional considera correcta, desde la perspectiva del acceso a los recursos, la doctrina del Tribunal Supremo que exige anticipar la cita de las normas y jurisprudencia que se entienden vulneradas en el escrito de preparación de la casación contra sentencias de la Audiencia Nacional. Sin embargo, esto atenta a la configuración legal del recurso de casación e implica una confusión entre la función del escrito de preparación y el de interposición; y tiene difícil acomodo en la jurisprudencia del TEDH. Tampoco es correcta la aplicación retroactiva de esta doctrina, desde la perspectiva de la confianza legítima. Otra cosa es que, lege ferenda, sea conveniente y aun necesario endurecer los requisitos del acceso a la casación, estableciendo como criterio general de admisión el interés casacional, a fin de que la Sala Tercera pueda cumplir adecuadamente sus funciones de unificación de doctrina y de defensa objetiva del Ordenamiento; pero se trata de una opción que corresponde al legislador.
\end{abstract}

Palabras clave: preparación de la casación; acceso a recursos; interés casacional.

\begin{abstract}
Constitutional Court considers that Supreme Court can impose new requisites in access to cassation; in spite of those requisites are not included in any act. However, this not only doesn't agree to legal cassation configuration, but also it's against European Court of Human Rights jurisprudence. Besides, retroactive application of this doctrine is against safety in Law. Lege ferenda certiorari system could be very useful, but this decision concerns to Legislative power.
\end{abstract}

Key words: access to cassation; certiorari. 


\section{SUMARIO}

I. LA CONFIGURACIÓN DE LA CASACIÓN EN EL ORDEN CONTENCIOSO-ADMINISTRATIVO: ENTRE LA TUTELA DE LOS DERECHOS DE LAS PARTES Y EL INTERÉS CASACIONAL.-II. EL PLANTEAMIENTO FÁCTICO EN LA STC 7/2015 Y LAS QUE SIGUEN SU DOCTRINA.III. LOS ARGUMENTOS DE LAS PARTES Y DEL TRIBUNAL CONSTITUCIONAL.-IV. LAS EXIGENCIAS FORMALES DEL ESCRITO DE PREPARACIÓN DEL RECURSO DE CASACIÓN FRENTE

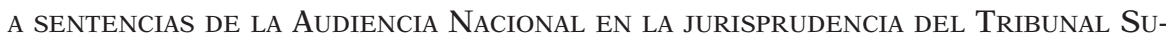
PREMO: EXAMEN CRÍTICO: 1 . Un nuevo requisito de admisibilidad del escrito de preparación no contenido en ninguna norma con rango de ley. 2. La aplicación del nuevo criterio a los recursos ya presentados con anterioridad a su establecimiento. 3. El discutible acomodo de la exigencia de requisitos de admisibilidad del recurso de casación creados jurisprudencialmente a la doctrina del TEDH.-V. CoNCLUSIONES.

\section{LA CONFIGURACIÓN DE LA CASACIÓN EN EL ORDEN CONTENCIOSO-ADMI- NISTRATIVO: ENTRE LA TUTELA DE LOS DERECHOS DE LAS PARTES Y EL INTERÉS CASACIONAL}

Posiblemente, una de las cuestiones más necesitadas de una profunda revisión dentro del proceso contencioso administrativo sea la configuración del recurso de casación ${ }^{1}$. La pregunta crucial que debemos hacernos es, naturalmente, si queremos un Tribunal Supremo - o una Sala de lo Contencioso-Administrativo del Tribunal Supremo, por ceñirnos a ella - cuya finalidad esencial sea tutelar los derechos e intereses de las partes en vía de recurso ${ }^{2}$; o si más bien sería preferible

1 Vid. O. BouazZa ArIÑo (2013), El recurso de casación contencioso-administrativo común, Civitas, Cizur Menor; J. M. SieIra Mínguez (dir.) y J. P. Quintana Carretero (2012), El recurso de casación en la jurisdicción contencioso-administrativa, Aranzadi, Cizur Menor; J. A. Domínguez Luis (1999), Los recursos de apelación y casación en la nueva Ley de la jurisdicción contencioso-administrativa, Madrid; I. C. IGLESIAS CONDE (2000), El recurso de casación contencioso-administrativo, Tirant lo Blanch, Valencia; V. GIMENo SENDRA (coord.) (2007), El Tribunal Supremo, su doctrina legal y el recurso de casación, Iustel, Madrid.

Sobre la casación antes de la Ley 29/1998, A. AgúNDEZ FERNÁNDEZ (1996), El recurso de casación contencioso-administrativo, Comares, Granada; J. J. GonZÁlEZ RIVAS (1996), El recurso de casación en la jurisdicción contencioso-administrativa, Aranzadi, Pamplona; A. TovaR MoRAIS (1993), El recurso de casación civil y el contencioso-administrativo, Aranzadi, Pamplona.

2 Vid. M. ORTELls Ramos, «El Tribunal Supremo español: un Tribunal en busca de identidad», en El Tribunal Supremo, su doctrina legal y el recurso de casación, cit., pág. 92; F. RAMOS MÉNDEZ, «¿Qué hacemos con el Tribunal Supremo?», en el mismo libro colectivo, págs. 133 y ss., donde el autor considera estéril la discusión sobre cuál debe ser el papel del TS, en la medida en que dicho papel debe ser definido por el legislador; J. E. PECES MorATE, «La jurisprudencia como guía y modelo en la función de juzgar», en el mismo volumen, págs. 421 y ss., para quien deben preservarse y compatibilizarse ambas finalidades, sin que deban ser disociadas; del mismo autor, «El papel del Tribunal Supremo en el orden contencioso-administrativo», en AA.VV., Balance de cinco años de aplicación de la Ley jurisdiccional, Consejo General del Poder Judicial, Madrid, 2004. Véase también R. GómEZ-FERRER RincóN (2007), 
configurar un modelo en que dicha Sala tenga como función la de unificar la doctrina, así como garantizar la defensa objetiva del Ordenamiento ${ }^{3}$.

A mi juicio, en una futura reforma de la LJCA seguramente sería más provechoso este segundo modelo: no se puede multiplicar indefinidamente el número de magistrados de la Sala de lo Contencioso-Administrativo por cuanto al final ésta devendría inoperante - demasiadas secciones; demasiados plenos, cuyas conclusiones, además, no siempre se siguen...-; y la función de tutela de los derechos e intereses de las partes, dada la elevada litigiosidad — aun tras la Ley de tasas judiciales ${ }^{4}$ y la reforma del sistema de costas por la Ley 37/2011-, exigiría dicha multiplicación ${ }^{5}$. La preservación de la función del TS, y más en concreto de su Sala de lo Contencioso-Administrativo, como órgano jurisdiccional superior en todos los órdenes, que exige el artículo $123 \mathrm{CE}$, sería mucho más sencilla y operativa con este sistema; ya que dicha función constitucional se preserva adecuadamente si se circunscribe a la defensa objetiva del Ordenamiento y a la unificación de doctrina.

Lógicamente, este segundo modelo exigiría dotar al TS de la potestad de decidir qué recursos se admiten y cuáles no deben ser admi-

«Recurso de casación y unidad del ordenamiento jurídico», RAP, 174, págs. 616 y ss. Asimismo, F. LEDESMA BARTRET (2006), «Tribunal Supremo y jurisdicción contencioso-administrativa», en Diagnosis de la jurisdicción contencioso-administrativa: Perspectivas de futuro, CGPJ, Madrid; J. A. XIOL Ríos (2004), «La posición constitucional del Tribunal Supremo», en El Tribunal Supremo en el ordenamiento constitucional. Jornadas en conmemoración del $X X V$ aniversario de la CE, Tribunal Supremo, Madrid, págs. 78 y ss.

3 Indica GómEz-FERRER RiNCón (2007: 616 y ss.) que no basta, para preservar la función objetiva del Tribunal Supremo y del recurso de casación, configurar aquél como mero órgano de unificación de doctrina, ya que la función constitucional del Tribunal Supremo, como órgano jurisdiccional superior en todos los órdenes, comprende también, y ante todo, la defensa objetiva del Ordenamiento frente a interpretaciones erróneas. En el mismo sentido puede verse el excelente trabajo de M. P. GARCía RuIZ (2008), «El Tribunal Supremo como mero órgano unificador de doctrina: la posible afectación de su garantía institucional», $R E D C$, 82, págs. 119 y ss., esp. págs. 165 y ss.

4 El Decreto-Ley 1/2015 exime en todo caso de la tasa a las personas físicas; lo que debe ser bienvenido.

5 La elevación de la summa gravaminis a 600.000 euros en la casación ordinaria sirve, desde luego, para disminuir la carga de trabajo del TS. Pero no es una medida suficiente, ni seguramente la más adecuada. Por ejemplo, para la casación para unificar doctrina, la summa gravaminis sigue siendo baja: 30.000 euros; y aunque es elevado el porcentaje de estos recursos que se inadmiten por falta de identidad con la sentencia de contraste, ello exige ya al TS un análisis que prácticamente es de fondo. Y, además, en cuanto a la cuantía, no se puede desconocer que hay asuntos de cuantía escasa que, sin embargo, podrían tener un elevado interés casacional, o que, pese a su escasa cuantía, resulten esenciales para los recurrentes - pensemos en personas de escasa capacidad económica, para las que unas pocas decenas de miles de euros pueden ser cruciales-. Así, el sistema ni sirve para proteger los derechos e intereses de las partes — salvo casos de muy elevada capacidad económica- ni sirve para preservar la función de unificación y de defensa objetiva del Ordenamiento que corresponde al TS. 
tidos, en función estrictamente del criterio del interés casacional objetivo, que debería apreciar en exclusiva el TS. Por supuesto, podrían establecerse criterios legales de apreciación de dicho interés casacional, lo que facilitaría las cosas; pero dichos criterios deberían ser objetivos, sin estar en función de cuestiones como la cuantía del recurso o los intereses de las partes ${ }^{6}$. Es más, para completar el sistema, se debería exigir motivación en las resoluciones de admisión, en su caso; nunca en las de inadmisión del recurso de casación, porque ésta sería la regla general. No habría que motivar la ausencia de interés casacional, sino en todo caso su concurrencia ${ }^{7}$. En suma, el interés casacional debería operar de forma generalizada como criterio de admisión, no su ausencia como criterio de inadmisión; si bien deberían establecerse algunas excepciones -impugnación de disposiciones generales y protección de derechos fundamentales ${ }^{8}$.

Este modelo encaja perfectamente dentro de las exigencias constitucionales de la tutela judicial efectiva, tal como viene siendo entendida por el Tribunal Constitucional. Esto es así porque cuando se trata de recursos contra resoluciones judiciales se entiende que el canon ya no es el principio pro actione, sino la ausencia de arbitrariedad o error patente; de forma que si este canon se cumple la resolución judicial que resuelve el recurso no podrá considerarse contraria a la tutela judicial efectiva ${ }^{9}$. Este argumento, como veremos, es controvertible desde el

6 Este modelo, además, debería ser extensible a todas las sentencias, incluso las dictadas por órganos unipersonales; todas deberían tener acceso a la casación si el Tribunal Supremo apreciara un interés casacional objetivo, bien por las exigencias de la unificación de doctrina, bien por las derivadas de la defensa objetiva del Ordenamiento. Vid. el informe elaborado en 2013 por la Comisión General de Codificación.

7 Partidario, asimismo, de potenciar el interés casacional como criterio de admisión se muestra BouAZZA ARIÑo (2013: 196). El autor, no obstante, considera que los criterios legales de la LJCA, esencialmente cuantitativos, no son los más adecuados. Vid., asimismo, GómezFERRER RINCÓN (2007: 631 y ss.). Una configuración distinta del interés casacional se aprecia en el artículo 477.3 LEC; sobre esta cuestión se puede ver el voto particular a la STC 46/2004, donde se analiza además la función objetiva del recurso de casación.

8 Tras la introducción por la LO 6/2007 de una configuración bastante semejante al certiorari en el recurso de amparo — desde el momento en que el mismo se puede inadmitir por simple providencia, sólo recurrible por el Fiscal—, quizá sería lógico reforzar el papel de las distintas Salas del Tribunal Supremo como última instancia de protección de los derechos fundamentales. Máxime si en una futura reforma de la Constitución terminara suprimiéndose el recurso de amparo. Lógicamente, el problema esencial estribaría en las sentencias que supuestamente infringieran el artículo $24 \mathrm{CE}$, sobre todo en vertientes como la motivación razonable en Derecho. La STEDH Arribas Antón, de 20-1-2015, ha entendido que la nueva configuración del recurso de amparo no vulnera el Convenio, ya que se trata de preservar el carácter subsidiario de este recurso; sin que el sometimiento del mismo a un requisito objetivo, como es la especial trascendencia constitucional, sea contrario al artículo 6 del Convenio.

9 Pueden verse E. Montoya MARTín (1997), El recurso de casación contencioso-administrativo: en especial, las causas de inadmisibilidad, MacGraw-Hill, Madrid, págs. 77 y ss.; S. MEDINA GONZÁLEZ (2009), La inadmisión del recurso de casación contencioso-administrativo, Thomson-Civitas, Cizur Menor. 
momento en que el TEDH utiliza, incluso en el acceso a los recursos contra resoluciones judiciales, el canon de la proporcionalidad. No obstante, y esto es lo esencial, el Tribunal Constitucional entiende que dicha arbitrariedad o error patente debe medirse atendiendo estrictamente a la configuración legal del recurso de que se trate; es decir, el derecho a los recursos es de configuración legal, y por tanto el derecho de acceso al recurso sólo existe en la medida en que la ley lo determine — dejando aparte el caso de las sentencias penales- Por tanto, si la ley establece que al recurso de casación sólo se podrá acceder cuando el TS aprecie interés casacional, el resultado será la inviabilidad del recurso de amparo contra las decisiones de inadmisión; ya que la admisión del recurso de casación en su configuración legal dependerá en exclusiva de la apreciación del TS. Y ello porque en el sistema así diseñado la regla será la inadmisión; y la excepción, la admisibilidad del recurso, cuya función ya no será la defensa de los intereses o derechos de las partes, sino la preservación del Ordenamiento jurídico y de la unidad de la doctrina -interés casacional objetivo-, aunque a consecuencia del ejercicio de dicha función los intereses de alguna de las partes resulten favorecidos $^{10}$.

Hoy por hoy, sin embargo, no es ésta la configuración legal del recurso de casación en la Ley 29/1998. En el modelo vigente del recurso de casación ordinario, lo que se protege esencialmente son los intereses de las partes. Es cierto que se da entrada al interés casacional, pero éste sólo juega en el caso de recursos de cuantía indeterminada y que no versen sobre impugnación directa ni indirecta de disposiciones generales; en este caso, aunque el recurso sea inicialmente admisible, el TS podría inadmitirlo por falta de interés casacional. O, lo que es lo mismo, la regla general, en el espíritu de la Ley, es la admisión; pero el TS podría exceptuarla por falta de interés casacional en ciertos casos ${ }^{11}$. Esta

10 Otro posible modelo sería establecer la admisibilidad general de la casación, pero estableciendo como excepción la ausencia del interés casacional. En ese caso, lo que habría que motivar sería la inadmisión basada en esta última causa. Este modelo no es conveniente; multiplicaría los recursos de amparo y, además, no frenaría la avalancha de recursos de casación, donde, sin embargo, las esperanzas de muchos recurrentes quedarían frustradas desde el principio.

11 La LJCA, como es sabido, introduce en este punto dos criterios en principio objetivos para apreciar la falta de interés casacional: que no afecte a un gran número de situaciones o que no posea el suficiente contenido de generalidad. Como indica J. L. MARTínez MoraLES (2015), Las técnicas de inadmisión en lo contencioso-administrativo versus la tutela judicial efectiva, discurso de ingreso en la Real Academia Valenciana de Jurisprudencia y Legislación, editado por dicha Academia, págs. 40 y ss., en un principio la Sala Tercera hizo un uso moderado de esta causa de inadmisibilidad del recurso de casación; pero a partir de 2010 se vuelve más restrictiva en cuanto a la admisibilidad de los recursos de cuantía indeterminada. El autor citado alude a la sentencia de 24-11-2011, que indica una serie de casos en que sí concurriría interés casacional; enumeración que recuerda a la que efectúan las SSTC 70 y 155/ 
previsión es absurda: se otorga al recurrente la confianza de que su resolución es recurrible; pero se condiciona a que no se aprecie falta de interés casacional. Si se quiere introducir el criterio del interés casacional debe hacerse a la inversa: la resolución no es recurrible; pero podría serlo si se apreciara por el TS el interés casacional.

$\mathrm{O}$, lo que es lo mismo, el sistema actual es un sistema híbrido, donde tenemos un conjunto de resoluciones que ex lege se consideran recurribles en casación; el resto de resoluciones en principio también lo son, pero el TS podría entender que falta ese «elemento objetivo» del interés casacional e inadmitir el recurso.

Es decir, en el modelo actual, con la salvedad de las resoluciones recurribles sólo por interés casacional —donde realmente no se sabe si la función de la casación es defender los derechos de las partes o más bien la defensa objetiva del Ordenamiento; o quizá ninguna de las dos $\operatorname{cosas}^{12}$-, el recurso de casación ordinario se configura esencialmente como un medio de tutela de los derechos e intereses de las partes; aunque constitucionalmente quepan otras opciones y aunque posiblemente este modelo no sea el más adecuado, a la vista del extraordinario volumen de recursos.

El funcionamiento del recurso de casación ordinario como medio de protección de los derechos e intereses de las partes, sin embargo, no resulta operativo. Aparte de la elevada cuantía que se exige para acceder a la casación con carácter general, no resulta operativo, en primer lugar, por el carácter marcadamente formalista del recurso de casación; formalismo acentuado por la interpretación de los requisitos de acceso a dicho recurso que efectúa la Sala Tercera, y sobre la que después me detendré. Resulta evidente que el TS no está para resolver cuestiones de hecho; por lo que el sistema de recursos ante el mismo no debe pivotar bajo el modelo de la apelación. Pero, quizá, si el legislador decidiera que la Sala Tercera sirve ante todo para defender los intereses y derechos de las partes, podría ser más operativo un modelo donde se ventilaran sólo cuestiones de Derecho pero sin necesidad de efectuar en

2009 en cuanto a la inadmisibilidad de los recursos de amparo. En dicha sentencia se alude a que esta causa de inadmisión tiene por finalidad preservar la función del TS como órgano unificador de doctrina. Sin embargo, esta afirmación poco sentido tiene, desde el momento en que existe una gran cantidad de resoluciones judiciales que son automáticamente recurribles en casación. Es decir, el criterio del interés casacional, o se generaliza, o de poco o nada sirve.

12 Porque la defensa de los derechos de las partes no se garantiza adecuadamente si se pone el filtro del interés casacional; pero la función unificadora y de defensa objetiva del Ordenamiento propia del recurso de casación tampoco se garantiza si este criterio se configura como causa de inadmisión frente a la regla general de la admisión, y además sólo para determinados casos. 
el escrito de interposición una acotación formal al correspondiente motivo legalmente tasado. En efecto, es sabido el elevado número de resoluciones en que el TS inadmite la casación porque lo que el recurrente ha calificado como vicio de incongruencia omisiva invocable al amparo del motivo c) del artículo 88.1 sería más bien un vicio de fondo incardinable en el motivo d), o viceversa; y ello incluso en casos en que el recurrente ha invocado un motivo o alternativamente el otro ${ }^{13}$. Los letrados de los recurrentes deben en ocasiones emplear muchas horas de trabajo, y mucha pericia, sólo en dilucidar correctamente qué motivos invocar, y de qué modo hacerlo; y la propia Sala Tercera podría ahorrarse muchas energías inútiles si el modelo se cambiara en el sentido indicado.

Pero, en segundo lugar, el control que ejerce el Tribunal Constitucional sobre las resoluciones de inadmisión, total o parcial, del recurso ordinario de casación es muy restringido, dada su doctrina sobre la configuración legal del acceso a los recursos, unida al carácter estrictamente formalista de la configuración legal del recurso de casación.

El resultado práctico de todo ello es un recurso de casación escasamente operativo. No sirve para proteger los intereses y derechos de las partes, o lo hace de forma muy imperfecta, debido a su carácter marcadamente formalista, acentuado por la interpretación que realiza la Sala Tercera; y debido asimismo a los cada vez más elevados requisitos de cuantía exigidos en muchos casos. Y no sirve para la unificación de doctrina ni para la defensa objetiva del Ordenamiento, ya que la existencia de ocho secciones y unos treinta y cinco magistrados hace ilusoria cualquier pretensión unificadora. A la vista de tan desalentadores resultados, seguramente sería preferible el sistema basado en exclusiva en el interés casacional; de hecho, las consecuencias terminarían siendo parecidas, teniendo en cuenta el elevado número de inadmisiones - cuya causa no siempre está clara-, pero, al menos, las reglas del juego serían conocidas por todos de antemano. Y, lo que es más importante, dichas reglas de juego serían predeterminadas por el legislador, no caso por caso por el TS.

13 Esto es así incluso tras la STEDH Sáez Maeso contra España, que estimó la demanda en un caso en que el recurso se había inadmitido por defectuosa incardinación del motivo casacional. La doctrina del TS no se ha rectificado porque el TEDH hizo hincapié en el transcurso de un largo tiempo entre la inicial admisión y la posterior inadmisión en sentencia; así como en la falta de audiencia previa a la inadmisión. Puede verse J. V. Mediavilla Cabo (2013), «El recurso de casación por infracción del art. 71-2 de la ley reguladora de la jurisdicción contencioso-administrativa», $R E D A$, 158, págs. 241 y ss., donde se pone de relieve la dificultad que en ocasiones concurre a la hora de incardinar una infracción en un motivo casacional u otro. 
Esta cuestión enlaza, justamente, con los problemas planteados por la STC 7/2015, de 22 de enero; sentencia a la que el TC ha dado importancia, dado que se trata de un recurso de amparo avocado por el Pleno. Aunque la sentencia termina estimando el recurso de amparo, de su lectura se llega a la sorprendente conclusión de que el acceso al recurso de casación ya no es sólo cuestión de configuración legal de los requisitos de dicho acceso, sino que se reconoce al mismo TS la potestad de configurar nuevos requisitos de acceso a la casación. Una cosa es la potestad, de la que no puede dudarse, que tiene el TS para interpretar los requisitos de acceso a la casación y otra que pueda crear nuevos requisitos; lo que, evidentemente, excede de dicha función interpretativa. El caso que va a comentarse, sin embargo, es un supuesto en que en realidad se crean requisitos nuevos de acceso por vía jurisprudencial; lo que el Tribunal Constitucional avala de un modo más o menos explícito.

La doctrina de esta sentencia se ha seguido por las SSTC 16, 17 y 20/2015. Las cuatro sentencias han sido objeto, además, de un voto particular. En todo caso, el fallo de la STC 16/2015 es desestimatorio; a diferencia de lo sucedido en los otros tres casos. En junio de 2015 ya se han dictado aproximadamente veinte sentencias más por el TC, que siguen la doctrina de las anteriores.

Si el acceso a la casación es de configuración legal, es obvio que dicha configuración legal debe respetarse en sus propios términos, sin añadir nuevos condicionamientos legalmente inexistentes. Se debe tener en cuenta al respecto que el TEDH ya ha efectuado diversas condenas a España debido a las prácticas del TS en la inadmisión de los recursos de casación, y no corregidas en vía de recurso de amparo; aun reconociendo el TEDH el carácter formalista del recurso de casación y el margen de apreciación que debe reconocerse a los órganos judiciales nacionales. La primera sentencia que así lo apreció, en relación con España, fue la de 28-10-2003, sobre la interpretación de los plazos ${ }^{14}$; las restantes versan sobre casos en que el recurso es inicialmente admitido - incluso en vía de recurso de queja en ocasiones- y, al cabo de un tiempo considerable, finalmente se dicta sentencia de inadmisión. No obstante, muchas de ellas combinan también la idea de que resul-

14 Puede verse E. GARcía DE EnTERría (2004), «La STEDH de 28-10-2003, Stone Court Shipping Company, S.A. c/España, y las prácticas judiciales españolas para inadmitir recursos», RAP, 163, págs. 169 y ss. La reciente STEDH Hassan Mohamed sí entiende correctamente inadmitido un recurso de casación por estar presentado fuera de plazo; ya que la demandante había alegado, pero no intentado probar, que el recurso se había presentado conforme a la regla del artículo 135 LEC, sobre presentación de escritos de término. Vid. BouAzZA ARIÑo (2013: 132 y ss.), donde indica que, pese a la doctrina de la sentencia del TEDH de 28-10-2003, el TS sigue exigiendo que el escrito de preparación se presente en tiempo y forma precisamente ante la Sala a quo. 
ta irrazonable el empleo que se da en ocasiones al argumento relativo a la falta de alegación del Derecho estatal o europeo.

En suma, sería perfectamente lícito - y posiblemente muy conveniente- que el legislador modificara el modelo de casación y configurara, más que un derecho de acceso a dicho recurso, una potestad del TS para admitirlo o rechazarlo a limine, según el interés del caso para la unificación de doctrina o para la preservación del Ordenamiento. Pero con el modelo actual, salvo en los casos en que opera el interés casacional como requisito de admisibilidad, existe un verdadero derecho al acceso a la casación cuando la resolución es recurrible y se cumplen los requisitos; requisitos que no son otros que los legales ${ }^{15}$.

\section{El PLANTEAMIENTO FÁCTICO EN LA STC 7/2015 Y LAS QUE SIGUEN SU DOCTRINA}

Esencialmente, en este caso los hechos se contraían a lo siguiente: una empresa obtuvo ante la Audiencia Nacional una sentencia parcialmente estimatoria contra una serie de resoluciones del TEAC. La Audiencia Nacional entendió que las liquidaciones eran conformes a Derecho, pero no las sanciones - que entendió amparadas en una interpretación razonable de las normas tributarias.

La sentencia de la Audiencia Nacional se dictó el 17-5-2010; contra ella, tanto la Administración estatal como los demandantes en la instancia prepararon su recurso de casación. La empresa, en dicho escrito de preparación, anticipó que su recurso se ampararía en el motivo d) del artículo 88.1 LJCA. En septiembre de dicho año la demandante en la instancia interpuso el recurso de casación; y en noviembre lo hizo la Abogacía del Estado.

Hay que aclarar que ni en el momento en que se preparó la casación y ni tan siquiera en el momento en que se formularon los respectivos escritos de interposición se había dictado todavía el auto del TS de 102-2011. Dicho auto, como es sabido, introdujo exigencias adicionales

15 Martínez Morales (2015: 58) critica con acierto la posición de la Sala Tercera en cuanto a la interpretación que realiza de la summa gravaminis. En efecto, señala el autor que cuando existen varios recurrentes y el objeto mediato del proceso es único para todos ellos - coherederos, comuneros...- la consideración individualizada de la cuantía correspondiente a cada uno de ellos por separado puede conducir a resultados absurdos; más aún si se tiene en cuenta que puede haber varios demandantes, pero para la demandada el objeto mediato tendrá el valor que tenga, sin división alguna. Sobre la cuantía como criterio de inadmisibilidad del recurso de casación, R. CANCIO FERNÁNDEZ (2008), El recurso de casación en el Derecho Administrativo económico: criterios de admisibilidad en la jurisprudencia del Tribunal Supremo, Bosch, Barcelona. 
para los escritos de preparación del recurso de casación frente a sentencias de la Audiencia Nacional, consistentes en la necesidad de que en dicho escrito se indique ya, de modo resumido, cuáles son las normas o la jurisprudencia que, al amparo del motivo d), se entiendan infringidas ${ }^{16}$. Pero poco después de que se dictara dicho auto el demandante en la instancia presenta en la Audiencia Nacional, el 31-3-2011, un nuevo escrito, que calificó como de adecuación del escrito de preparación a las nuevas exigencias impuestas por el ATS de 10-2-2011 ${ }^{17}$.

Sin embargo, tras su presentación se dio audiencia a ambas partes sobre posible inadmisión de ambos recursos de casación, por omisión de las exigencias formales del escrito de preparación. La parte demandante alegó que, pese a lo indicado en dicho auto, con posterioridad, la STS de 30-3-2011 sí había entendido admisible un recurso de casación contra una sentencia de la Audiencia Nacional, aun cuando en

16 Sobre los escritos de preparación e interposición de la casación, J. ORTIz Ríos (1994), «El recurso de casación en el proceso contencioso-administrativo: los escritos de preparación e interposición», REDA, 81, págs. 105 y ss.; M. FuERTES LóPEZ (1993), «El escrito de preparación del recurso de casación», Poder Judicial, 32; J. R. RodRíGuez CARBAJo (2003), «La preparación del recurso de casación contencioso-administrativo», Actualidad Administrativa, 31, págs. 765 ss.

Sobre la evolución de la jurisprudencia del TS en este punto, J. R. RodRíGuez CARBAJO (2011a), «El Auto que puede descongestionar la Sala Tercera del Tribunal Supremo», Actualidad Administrativa, 9; (2011b), «El estado actual de la nueva doctrina del TS sobre el escrito de preparación de la casación ordinaria», Actualidad Administrativa, 15; así como (2015), "Los diversos escritos preparatorios del recurso de casación (I)», Actualidad Administrativa, 3, pág. 4; y también (2011c y d), «La nueva doctrina del TS sobre los escritos de preparación del recurso de casación ordinario (I)», Actualidad Administrativa, 6, pág. 3, y (II), en la misma revista, 7, pág. 4. Este autor, en todo caso, subraya que cuando se invoca el motivo c), en vez del motivo d), no se aplica la exigencia de citar las normas y jurisprudencia que se consideran infringidas; y añade que el ATS de 8-3-2012 y la STS de 5-11-2012, entre otras resoluciones, no consideran dicha exigencia aplicable a la casación contra autos.

Puede verse también, sobre esta evolución, J. A. Santamaría Pastor y A. Arévalo GutiéRREZ (2011), «Aviso para navegantes: la cambiante jurisprudencia sobre el escrito de preparación en la casación contencioso-administrativa», Actualidad Jurídica Aranzadi, 821, para quienes la nueva doctrina no descongestionará en la práctica al Tribunal Supremo; M. A. RuIZ LóPEz (2011), «La intensificación de las exigencias formales del recurso de casación», REDA, 150, págs. 471 y ss., donde comenta el ATS de 10-2-2011; sobre ese auto, también C. CHINCHILLA MARín (2011), «La admisión del recurso de casación contra sentencias y autos de la Audiencia Nacional», Justicia Administrativa, 52, págs. 27 y ss. Esta nueva doctrina pone de relieve que la interpretación que el TS efectúa del artículo 86.4 no sólo se debe a la «deferencia» a los TSJ, sino además a la sobrecarga de trabajo. Pero la solución estriba en configurar adecuadamente el interés casacional como criterio de admisión.

17 Como señala BouAzza ARIÑo (2013: 140), con posterioridad al ATS de 10-2-2011 y el de 10-11-2011 ha habido otros en el mismo sentido; como los de 15-3-2012, 12-4-2012, 7-6-2012 o el de 10-5-2012, que exige además cita concreta de preceptos y no la cita genérica de normas ya en el escrito de preparación. El autor, no obstante (2013: 153), pone asimismo de relieve que el mismo día 7-6-2012 se dictó otro auto en sentido contrario, donde se afirma que la exigencia de exposición de los motivos lo es del escrito de interposición, y no del escrito de preparación. Hoy, la doctrina del ATS de 10-2-2011 se halla plenamente consolidada; y así se pueden citar los AATS de 19-2-2015 y varios de 5-2-2015, así como los de 15 y 22-1-2015, por citar los más recientes. 
el escrito de preparación no se citaban las normas ni jurisprudencia infringidas ${ }^{18}$. Finalmente, el auto de 10-11-2011 aplica la doctrina del auto de 10 de febrero de dicho año e inadmite ambos recursos de casación por el motivo apuntado ${ }^{19}$.

En el caso de la STC 16/2015, la casación tanto del actor como del Abogado del Estado frente a la sentencia de la Audiencia Nacional fue inadmitida por auto de 22-9-2011, que insiste en que la nueva exigencia jurisprudencial del escrito de preparación tiene su base en la necesidad de permitir que el órgano a quo realice un primer análisis sobre la viabilidad del recurso de casación; así como proporcionar a la parte recurrida información respecto a los motivos en que se fundamentará dicho recurso, sin que la Sala a quo pueda de oficio complementar siquiera dicha carga procesal ${ }^{20}$.

\section{Los ARgumentos DE LAS PARTES y DEL TRIBUnAL CONSTITUCIONAL}

Empezando por la STC 7/2015, en el incidente de nulidad de actuaciones el demandante aducía la infracción del principio de igualdad en la aplicación de la ley, ya que la doctrina del ATS de 10-2-2011 no es unánime dentro del TS; de forma que hay otras resoluciones posteriores en que la casación frente a las sentencias de la Audiencia Nacional se estima admisible pese a no haberse citado en el escrito de preparación las normas y jurisprudencia infringidas. En suma, se trataría de un cambio arbitrario y sin vocación de permanencia.

La arbitrariedad y falta de razonabilidad del nuevo criterio vendrían dadas porque se exige un requisito legalmente inexistente, con infracción del derecho de acceso a los recursos. Y, además, al haberse aplicado la nueva doctrina en relación con recursos de casación ya pre-

18 No obstante, se trataba de un recurso de casación ya admitido al tiempo de dictarse el auto de 10-2-2011.

19 Tal como indica Martínez Morales (2015: 31 y ss.), antes del ATS de 10-2-2011 la respuesta del TS era distinta. Cita así el ATS de 12-7-2007, que indica que la expresión de los motivos casacionales es requisito del escrito de interposición, pero no del escrito de preparación. El autor señala que fue en 2009 cuando se introdujo un mayor rigor en cuanto al escrito de preparación frente a sentencias de un TSJ; en 2010, los AATS de 18-11 y de 14-10 exigirían la expresión formal de los motivos en los escritos de preparación contra las sentencias de la Audiencia Nacional.

20 Por su parte, la STC 20/2015 resuelve un recurso de amparo contra otro auto de inadmisión por defectuosa preparación de la casación contra una sentencia de la Audiencia Nacional, basado en la misma doctrina del ATS de 10-2-2011; en un caso en que el escrito de preparación se había presentado el 11 de febrero de dicho año, cuando el auto ya se había dictado pero todavía no se había hecho público. En este caso, el auto recurrido en amparo iba fechado el 9-2-2012. En el caso de la STC 17/2015, la casación se había tenido por preparada en 2010; y el auto de inadmisión es de 10-11-2011. 
sentados con anterioridad, retroactivamente, se habría infringido la seguridad jurídica. Por lo demás, añadía el incidente de nulidad de actuaciones, se habría vulnerado la jurisprudencia constitucional referente a la posibilidad de subsanar defectos procesales.

En el recurso de amparo, el demandante insistía en la lesión de su derecho a la tutela judicial en su vertiente del derecho de acceso a los recursos, habida cuenta del cambio retroactivo de criterio, que introduce además requisitos no previstos legalmente ni exigidos en la jurisprudencia existente al tiempo de la preparación de la casación; por todo lo cual la demanda de amparo consideraba que el auto carecía de motivación en Derecho y, además, resultaba arbitrario. Se insistía en que nos encontramos ante un cambio impredecible de criterio; asimismo, en la falta de vocación de permanencia del nuevo criterio, que incidiría en la infracción del principio de igualdad en la aplicación de la ley.

Y se alegaba asimismo que debió haberse tenido en cuenta la diligencia del recurrente, que, a la vista del auto de 10 de febrero, inmediatamente presentó escrito de subsanación del escrito de preparación ${ }^{21}$.

Hay que resaltar que en este caso incluso el Abogado del Estado, parte recurrida, entendía que efectivamente se había vulnerado el principio de protección de la confianza legítima, con infracción de la tutela judicial efectiva en su vertiente de acceso a los recursos 22 ; y ello debido a la aplicación retroactiva de un nuevo régimen procesal desfavorable. El Ministerio Fiscal, por su parte, adujo que, a fin de cuentas, el ATS de 18-11-2010 había tenido la pretensión de unificar doctrina en

21 Bouazza Ariño (2013: 130) indica que en caso de que concurran defectos en el escrito de preparación deberían entrar en juego los artículos 138 LJCA y 11.3 LOPJ —vid. asimismo RuIZ LóPEZ (2011: 472)—; incluso considera que, en aras del principio pro actione, los defectos del escrito podrían darse por subsanados acudiendo a actuaciones posteriores - también, RuIz López (2011: 480)—. Esto enlaza además, como veremos, con la interpretación finalista que realiza el TEDH, para quien lo importante es que la actuación del recurrente sea suficiente para que se pueda ejercer el control casacional. El autor, en todo caso, añade que aunque ésta fue la línea en principio seguida por el TS, más adelante éste ha dado un giro hacia posiciones mucho más formalistas. Vid. asimismo BoUAZZA ARIÑo (2013: 145 y ss.), en relación con la doctrina jurisprudencial que considera insubsanable la omisión del juicio de relevancia exigido por el artículo 89.2 para la preparación de la casación contra sentencias de los TSJ; por considerarlo un requisito material y no formal — con el aval de las SSTC 181 y 230/2001-. El autor (2013: 176 y ss.) trata el problema inverso: la posible integración del escrito de interposición con el de preparación cuando aquél no expresa los motivos y sí lo hace éste. Asimismo, RuIz López (2011: 479 y ss.) indica que en ocasiones el TS ha efectuado una valoración conjunta de ambos escritos, en aras del principio pro actione.

FuERTES LÓPEZ (1993: 253) se inclinaba por la posibilidad de subsanación de los defectos del escrito de preparación.

22 Sin embargo, entendió que no se trataba de una resolución aislada o ad hoc, sino inserta en determinada línea jurisprudencial, iniciada con el ATS de 10-2-2011. El Ministerio Fiscal, en cambio, sí argumentó la estimación de la demanda con base en la igualdad en la aplicación de la ley. 
cuanto a los requisitos formales del escrito de preparación frente a sentencias de la Audiencia Nacional; y dicho auto «unificador» se había limitado a exigir la cita formal de los motivos casacionales genéricos del artículo 88.1 que fueran luego a desarrollarse ${ }^{23}$. Sin embargo, esta doctrina «unificadora» fue abandonada por el auto de $10 \mathrm{de}$ febrero, que introduce ex novo requisitos no exigidos en la Ley; sin que además, a juicio del Ministerio Fiscal, se explicitaran las razones del cambio de criterio $^{24}$. A todo ello añadía que la doctrina del auto de 10 de febrero no es unánime; y así cita en contra los AATS de 17-2, 24 y 17-3 y 16-6-2011; y las sentencias de 30-3 y 5-4-2011. Todo ello, a juicio del Ministerio Fiscal, constituía un término válido de comparación; al menos, aquellas resoluciones asimismo dictadas por la Sección Primera, autora del auto recurrido en amparo, y relativas a la casación contra sentencias de la Audiencia Nacional25. Al menos cuatro autos, señala el Fiscal, servirían como término válido de comparación. Por todo ello, entendía que se había vulnerado la igualdad en la aplicación de la ley.

La sentencia 7/2015, finalmente, estima el recurso de amparo. Sin embargo, ni entiende vulnerado el principio de igualdad en la aplicación de la ley, ni entiende vulnerado el derecho de acceso a los recursos contra resoluciones judiciales. En cuanto a lo primero, observa el TC que existen dos líneas jurisprudenciales sobre los requisitos de admisibilidad del escrito de preparación de la casación que coexisten; de manera que no se puede decir que el auto que nos ocupa haya sido una resolución ad personam y, por tanto, discriminatoria. En segundo lugar, tampoco entiende vulnerado el derecho de acceso a los recursos. En tal sentido, indica el TC que el derecho de acceso a los recursos es de configuración legal; de forma que sólo existe cuando lo dice el legislador y con los límites configurados por éste. Y además, añade el TC, de acuerdo con su reiterada doctrina, el control que en vía de recurso de amparo se puede ejercer sobre el derecho de acceso a los recursos es meramente externo, ya que en este caso no juega el principio pro actione; de forma que, siempre que exista motivación, sólo se encuentran vedadas las resoluciones arbitrarias, irrazonables o incursas en error pa-

23 Sobre esta evolución, Bouazza ARIÑo (2013: 148 y ss.); CHINCHILla MARÍN (2011: 31 y ss.).

24 Por el contrario, en el caso resuelto por la STC 17/2015, el Fiscal entendía vulnerado el principio de igualdad, pero no el derecho a la tutela judicial efectiva; al considerar que la doctrina del ATS de 10-2-2011 y los que siguen su doctrina tendría su base legal en el artículo 88.1.c) y d) LJCA.

25 En cambio, en el amparo resuelto por STC 16/2015, el Ministerio Fiscal era partidario de su desestimación, al entender que no existía arbitrariedad ni error patente; sin que tampoco entendiera viable la alegada infracción del principio de igualdad, por entenderla carente de desarrollo argumental. 
tente, pero sin que el TC pueda ejercer un control de proporcionalidad. Y todo ello, añade el TC, se refuerza si se tiene en cuenta el carácter extraordinario del recurso de casación, que sólo cabe por motivos tasados y que se halla sometido a rígidas formalidades procesales — todo ello con cita de otras sentencias, como la 35/2011 y la 100/200926.

Para el TC, nos encontramos ante el ejercicio de la función interpretativa del derecho de acceso a los recursos por parte del TS; sin que en su ejercicio se haya incurrido en irracionalidad o arbitrariedad $^{27}$.

La estimación del amparo se basó en que, en este caso, el recurrente en casación había presentado un escrito ante la Audiencia Nacional, tras conocer el ATS de 10-2-2011 — que cambiaba el criterio y añadía nuevos requisitos formales al escrito de preparación-, a fin de adecuar la preparación del recurso de casación a las exigencias contenidas en dicho auto; y, aun así, la casación fue inadmitida. Es decir, el TC entiende que es relevante que el escrito de preparación fuera anterior al auto de 10-2-2011; y que el recurrente trató de "subsanar el defecto». Y, además, que lo hiciera con gran celeridad, ya que el escrito se había presentado el día 31-3-2011. En el caso de la STC 16/2015, el fallo fue desestimatorio; ya que aquí el recurrente no había intentado «subsanación» alguna.

\section{LAS EXIGENCIAS FORMALES DEL ESCRITO DE PREPARACIÓN DEL RECURSO DE CASACIÓN FRENTE a SENTENCIAS DE LA AUdiENCIA NACIONAL EN LA JURISPRUDENCIA DEL TRIBUNAL SUPREMO: EXAMEN CRÍTICO}

\section{Un nuevo requisito de admisibilidad del escrito de preparación no contenido en ninguna norma con rango de ley}

El requisito de la cita de las normas legales y jurisprudencia infringidas ya desde el escrito de preparación, antes del ATS de 10-2-

${ }^{26}$ Cita también la STC 248/2005, que aplica la doctrina Sáez Maeso y estima el recurso de amparo.

27 «De acuerdo con la jurisprudencia de este Tribunal sobre el ámbito del derecho al recurso en relación con la protección del derecho a la tutela judicial efectiva y su alcance en relación con el recurso de casación, la integración de este requisito procesal, en su doble condición de expresión en el escrito de preparación de los motivos del recurso y de los concretos preceptos legales vulnerados y jurisprudencia infringida, entra dentro de las facultades jurisprudenciales que corresponden al Tribunal Supremo en la interpretación de la ley sobre los requisitos de acceso a la casación; y, en consecuencia, la alegación debe ser desestimada». Una cosa es interpretar y otra añadir requisitos que no se encuentran en la norma. Máxime cuando ni siquiera de la conjunción sistemática del Ordenamiento se deduce que ese añadido de nuevos requisitos es la única respuesta posible; de hecho, durante mucho tiempo dicha postura no se mantuvo por el TS. 
2011, sí había venido exigiéndose en relación con las sentencias de los TSJ; al entender el TS que de otro modo no se podría garantizar el cumplimiento del requisito de la relevancia del Derecho estatal y europeo ${ }^{28}$. Tiene en cuenta al respecto el TS que el artículo 89.2 LJCA exige que dicho juicio de relevancia conste ya en el escrito de preparación.

La novedad del ATS de 10-2-2011, luego seguido por resoluciones posteriores - por ejemplo, el ATS de 28-11-2013-, estriba en que la exigencia de hacer constar en el escrito de preparación, siquiera someramente, las normas y jurisprudencia infringidas se extiende a las sentencias de la Audiencia Nacional; donde, obviamente, no juega el requisito del juicio de relevancia del Derecho estatal o europeo ${ }^{29}$. Y, por supuesto, y al igual que sucede en relación con las exigencias del escrito de preparación frente a sentencias dictadas por los TSJ, el TS viene entendiendo que la omisión de dicho requisito no resulta subsanable a través del escrito de interposición. Es decir, aunque el escrito de interposición sí encuadre adecuadamente los motivos casacionales y cite las normas y jurisprudencia infringidas, ello no subsana la omisión de dicha cita somera en el escrito de preparación.

El razonamiento sobre el que gira el ATS de 10-2-2011, y los que siguen su doctrina, estriba en que en caso de no exigirse ni siquiera la cita somera de los preceptos legales y jurisprudencia que se estiman in-

28 Vid. J. M. Alonso Furelos, «El juicio de relevancia en el recurso de casación contencioso-administrativo por infracción de los TSJ de las Comunidades Autónomas de una norma estatal o comunitaria relevante y determinante del fallo», en El Tribunal Supremo, su doctrina legal y el recurso de casación, cit., págs. 206 y ss. En todo caso, no basta la cita de las normas y jurisprudencia, sino que hay que argumentar asimismo su carácter relevante y determinante para el fallo.

29 Con anterioridad, tal como expone la STC 7/2015, algunos autos del TS ya habían exigido, respecto de las sentencias de la Audiencia Nacional, la anticipación en el escrito de preparación de los motivos casacionales que después se invocarían en el escrito de interposición, tal como hemos visto; si bien en otras resoluciones se consideró que ello sólo sería exigible en las sentencias de los TSJ. Concretamente, afirma la STC 7/2015: "Más adelante, algunas resoluciones del Tribunal Supremo (AATS de 3-12-09, recurso de casación 577-09; 4-3-10, recurso de casación 4416-09, y 6-5-10, recurso de casación 6228-09) comenzaron a entender exigible con carácter general en los escritos de preparación del recurso de casación la expresión de los motivos de casación que iban a desarrollarse en el escrito de interposición. Tal exigencia no era general, pues, como declaran los AATS de 14-10-10, recursos de casación 951-2010 y 573-10; 18-11-10, recurso de casación 3461-2010; 25-11-10, recursos de casación 1886-10 y 2738-10; y 2-12-10, recursos de casación 3852-10 y 5030-10, debe reconocerse que en ocasiones tal exigencia se ha predicado tan sólo respeto de los recursos de casación preparados frente a sentencias de las Salas de lo Contencioso-administrativo de los Tribunales Superiores de Justicia, excluyéndose expresamente esta exigencia respecto de las sentencias de lo Contencioso-administrativo de la Audiencia Nacional (en este sentido, Autos de esta Sala y Sección de 23-4-09, recurso de casación 3146-08, 9-7-09, recurso de casación 5647-08 y 64-10, recurso de casación 1368-09, entre otros)». Añade el TC que en autos de 14-10 y 18-112010 la Sección Primera de la Sala Tercera clarificó que, efectivamente, la anticipación de los motivos casacionales genéricos era también exigible en los escritos de preparación frente a sentencias de la Audiencia Nacional. 
fringidos se frustraría la finalidad del escrito de preparación y se convertiría éste en un trámite inútil; ya que el órgano a quo no podría realmente verificar si la casación es o no viable a limine. De hecho, el TS señala que la preparación de la casación debe tener sustantividad propia y no resultar un mero formalismo.

Y además, añade el auto, la parte recurrida tampoco podría adoptar la posición procesal pertinente ${ }^{30}$. A esto se puede, no obstante, contraargumentar que la parte recurrida nada tiene que decir frente al escrito de preparación, ya que el momento de su defensa está en su escrito de oposición a la casación, que se formula frente al escrito de interposición. Es en ese momento procesal donde la parte recurrida puede aducir que la casación, en su caso, por unos u otros motivos, resulta inadmisible. Es cierto que el artículo 90.3 LJCA indica que si bien frente a la resolución por la que se tiene por preparado el recurso de casación no cabe recurso alguno, sin embargo, la parte recurrida puede oponerse a su admisión en el término del emplazamiento. Sin embargo, también lo es que la parte recurrida puede desplegar todas sus posibilidades de defensa frente al escrito de interposición.

No sólo eso. El artículo 93 regula el trámite de inadmisión del recurso de casación, donde se distingue claramente el motivo de inadmisión consistente en la concurrencia de defectos en el escrito de preparación del caso en que en el escrito de interposición no se hubieran dictado las normas o la jurisprudencia que se estiman infringidas, o éstas no guardan relación alguna con las cuestiones objeto del debate. Y, dentro de lo que son los defectos del escrito de preparación, se alude de forma expresa a la posibilidad de que la Sala, de oficio, rectifique la cuantía a efectos de la summa gravaminis. Pues bien, el apartado tercero del artículo 93.3 señala, además, que la posible causa de inad-

30 Posiblemente, en realidad, el endurecimiento de los requisitos formales en el acceso a la casación tenga que ver con la atribución a los Secretarios judiciales, por la Ley 13/2009, de la competencia para considerar como preparado el recurso de casación, conforme al artículo 90.1 LJCA; de modo que sólo si el Secretario considera que el escrito no es viable lo elevará a la Sala para que ésta resuelva. Es decir, quizá subyaga implícitamente cierta desconfianza por parte del TS hacia la labor en este punto de los Secretarios judiciales. Éstos son muy buenos conocedores de la normativa procesal y de los requisitos de su aplicación, pero no están obligados a conocer al detalle cuestiones sustantivas muy problemáticas, como la relación entre el Ordenamiento estatal y el autonómico a los efectos del juicio de relevancia. Sin embargo, el problema estriba en que el ATS de 10-2-2011 y los que siguen su doctrina se refieren a sentencias de la Audiencia Nacional, donde no se halla en juego el juicio de relevancia. Además, a fin de cuentas, la competencia para tener por preparado el recurso de casación concierne al Secretario por determinación legal; y ello es así por mucho que se hayan incrementado las exigencias formales del escrito de preparación. Quizá, el establecimiento de esas nuevas exigencias aparentemente formales, pero que se concretan en la cita de normas sustantivas, busque la remisión a la Sala del escrito de preparación en todos los casos. 
misión se debe poner de manifiesto a las partes personadas para alegaciones; no sólo al recurrente, sino también a los recurridos.

Es decir, en realidad poco tiene que ver la defensa o estrategia procesal de la parte recurrida, que siempre podría aducir lo procedente en el trámite de inadmisión que puede abrir la Sala, artículo 93.3; trámite de inadmisión que además se abre una vez interpuesto el recurso de casación, que es donde se deben desarrollar los motivos casacionales, conforme al artículo 92.1.

Y, en cuanto a la funcionalidad del escrito de preparación, la LJCA lo configura como algo distinto del escrito de interposición. Su función es meramente formal y externa: verificar que la resolución es recurrible en casación, y que el escrito se ha presentado dentro del plazo de diez días, básicamente. El escrito de preparación sólo cumple además una función sustantiva cuando se trata de sentencias de los Tribunales Superiores de Justicia. De hecho, además, ello es coherente con la competencia del Secretario judicial para tener por preparado el recurso de casación ${ }^{31}$; notemos que, por el contrario, no sólo la inadmisión, sino también la admisión de la casación, a la vista del escrito de interposición, corresponde, conforme al artículo 93 LJCA, a la Sección correspondiente, sin que intervenga el Secretario judicial. Esto supone que una cosa es la función del escrito de preparación, puramente formal con la salvedad del juicio de relevancia en las sentencias de los TSJ; y otra la función del escrito de interposición ${ }^{32}$.

Es más, de la STEDH Sáez Maeso se desprende que no es viable dar por bien preparado un recurso de casación e inadmitirlo largo tiempo después. Esto pone en tela de juicio, posiblemente, no sólo la interpretación que realiza el TS de los requisitos del escrito de preparación, sino también la misma funcionalidad y sentido del escrito de preparación $^{33}$.

31 Tal como indica ORTIz Ríos (1994: 106), tiene sentido esta distinción legal, ya que la Sala a quo no puede entrar en la procedencia o improcedencia de los motivos del recurso de casación —-menos aún el Secretario judicial, quien se pronuncia prima facie sobre la admisión del escrito de preparación-. Por su parte, RodríguEZ CARBAJo (2011b: 1) señala que la LJCA, artículo 89.1, alude sólo a requisitos «de forma», ante las dudas surgidas por la redacción de la Ley 10/1992 en cuanto a los requisitos del escrito de preparación.

32 En el voto particular al ATC 3/2000 se indica: «conviene deslindar los dos escritos sobre los que gira la casación y que convienen a cada una de sus sucesivas fases: En el de preparación, se ha de hacer patente ante el Tribunal a quo que la Sentencia por él dictada es susceptible del recurso (no está excluida), que se intenta en plazo y por quien ostenta gravamen para promoverlo, es decir, que concurren los requisitos para su inicial procedencia. En tal escrito preparatorio no se ha de contener la fundamentación del recurso, lo que pertenece, articulando los motivos pertinentes, a la fase de interposición ante la Sala Tercera del Tribunal Supremo».

33 Indica con acierto Martínez Morales (2015: 38) que realmente con estas nuevas exigencias formales del escrito de preparación, el mismo prácticamente se convierte en la avan- 
Desde este punto de vista, anticipo que, en relación con las sentencias de la Audiencia Nacional, la exigencia de estos nuevos requisitos formales me parece no sólo desproporcionada, sino carente de fundamento racional suficiente. Parece más bien una medida paliativa frente al indudable exceso de trabajo del TS.

Pero, además, y esto es lo esencial, se introducen requisitos que no están en la ley ${ }^{34}$; lo que no se adecúa a la configuración del derecho de acceso a los recursos frente a resoluciones judiciales como derecho de configuración legal ${ }^{35}$. Es decir, una cosa es que la tutela judicial efectiva se module cuando estamos ante el acceso a los recursos contra resoluciones judiciales, en tanto en cuanto el acceso a los recursos existirá sólo y en la medida en que la ley lo determine. Pero debe ser el legislador quien establezca los recursos y los requisitos de su admisibilidad ${ }^{36}$. El

zadilla del escrito de interposición. Pero la duda del autor gira entonces sobre lo siguiente: ¿para qué queremos, pues, el escrito de preparación? Es decir, ¿no sería más coherente suprimir el escrito de preparación? Pensemos que, por ejemplo, en la casación para unificar doctrina dicho escrito de preparación es inexistente; y nadie se lleva las manos a la cabeza por ello. Y, a fin de cuentas, pasar el filtro del escrito de preparación nada significa; bien claro lo dice el artículo 93. Puede verse BouAzZA ARIÑo (2013: 129), quien señala que nos encontramos con un doble trámite de control que no es indispensable y que provoca una dilación innecesaria; máxime, añade el autor, cuando ni la resolución dándolo por bien preparado ni la resolución de admisión son vinculantes para el Tribunal Supremo, que incluso puede inadmitir en sentencia. El autor (2013: 153) indica que el TS está literalmente creando normas jurídicas inexistentes previamente y usurpando las atribuciones del legislador; ya que la LJCA es clara en cuanto a los requisitos del escrito de preparación. Por su parte, RuIz López (2011: 476) indica que, además, si se supera la fase de preparación pero no la de admisión, la consecuencia será la condena en costas al recurrente, conforme al artículo 93.5 LJCA.

También L. Cosculluela Montaner (2005), Manual de Derecho Administrativo, 16 . $^{\text {a }}$ ed., Thomson-Civitas, Madrid, págs. 562 y ss., entiende que lege ferenda se debería suprimir el trámite de preparación; añade que no debería inadmitirse el recurso por defectos en el escrito de preparación, en la medida en que, integrado con el escrito de interposición, puede ser suficiente para ejercer un correcto control casacional. Y RoDRíGUEZ CARBAJO (2015: 2) entiende que esa dualidad de escritos no es consustancial a la casación; y resalta su supresión en la casación civil por la Ley de agilización procesal, 37/2011.

34 Así, Bouazza ARIÑo (2013: 150), quien también subraya que la LJCA diferencia el contenido del escrito de preparación y el del escrito de interposición.

35 El TC intenta salir al paso de este argumento transcribiendo un párrafo de la STC 74/1983, de acuerdo con el cual no existe lesión de la tutela judicial cuando, en ausencia de estricta prescripción legal, son los tribunales quienes estructuran las formalidades procesales que estiman adecuadas a la situación. Pero no es el caso; la LJCA sienta muy claramente cuáles son los requisitos - - legales, claro- de acceso a la casación, y diferencia los propios del escrito de preparación y los del escrito de interposición.

36 Así, el voto particular a la STC 46/2004 indica: «desde el momento en que el legislador establece un determinado y específico recurso contra determinadas resoluciones judiciales, viene a reforzar la efectividad de la tutela judicial de los derechos e intereses legítimos que puedan verse afectados, respecto de los cuales tal efectividad de la tutela judicial ya no sólo se satisface con una respuesta judicial que reúna las características de lo razonable y no arbitrario o incurso en error patente, sino que viene a exigir que debe permitirse el acceso a un concreto recurso a fin de que en el mismo se obtenga una segunda o ulterior decisión en torno a aquellos derechos e intereses legítimos, aun controvertidos, dotada también de las apuntadas características. Es el legislador, precisamente en esa labor de configuración que le co- 
TS no puede crear nuevos requisitos que no se encuentran en la ley. Esto no es función del TS, sino del legislador. El TS tiene como función interpretar los requisitos de acceso a esos recursos; pero no tiene como función crear requisitos que no se hallan en la ley ${ }^{37}$. Y la línea jurisprudencial que nos ocupa, a la vista de lo indicado, crea un nuevo requisito; con claro exceso sobre lo que es la función de interpretación. La interpretación debe actuar sobre los requisitos comprendidos en la norma legal; pero no abarca adicionar nuevos requisitos ${ }^{38}$. Así, CHINCHILLA MARÍN ${ }^{39}$, con todo acierto, señala que el principal problema de esta doctrina jurisprudencial estriba - además de en haberse apartado de otra muy reciente en aquel momento y que tenía pretensiones de ser definitiva- en la falta de sustento legal de este nuevo requisito del escrito de preparación; ya que dichos requisitos se encuentran en el artículo 89, que no menciona el que nos ocupa.

rresponde en relación con el derecho fundamental que consideramos, el que determina, en ejercicio de su margen de apreciación, cuál es el concreto grado de efectividad que precisa la tutela judicial de los derechos e intereses legítimos (en este sentido, STC 115/02, citada, FJ 5), considerando en ciertos supuestos que la misma exige la previsión de un específico recurso contra determinada resolución judicial».

37 El ATC 400/2014 inadmite un recurso de amparo contra un auto de la Sala de lo Civil del TS, que a su vez había inadmitido un recurso de casación. El problema estribaba en que la sentencia se había dictado por un Magistrado de la Audiencia Provincial, que actuaba como tribunal unipersonal. La Sala Primera interpretó que la casación sólo cabe contra resoluciones de los órganos colegiados, sin que pueda predicarse esta condición cuando la sentencia se dicta por un solo Magistrado, aunque sea de la Audiencia Provincial. Éste sí es un caso en que se realiza una interpretación de los requisitos de acceso a la casación —que la sentencia provenga de un tribunal colegiado-; interpretación restrictiva pero que no implica en realidad crear nuevos requisitos no previstos legalmente. La diferencia con nuestro caso es evidente.

38 Algo parecido sucede, aparentemente, con la interpretación que la Sala Tercera sostiene en relación con los asuntos que con la LO 19/2003 pasaron a ser competencia de los juzgados, cuando la sentencia se hubo dictado en primera instancia por el TSJ al haberse presentado el recurso contencioso administrativo con anterioridad a su entrada en vigor. Pero existen dos diferencias. Primero, en este caso sí existe base legal, ya que aunque la LO 19/2003 carece de disposiciones transitorias al respecto, sin embargo, la LJCA sí contiene una norma transitoria que impide la presentación de recursos de casación contra sentencias dictadas por los TSJ en asuntos que con la Ley 29/1998 hubieran pasado a ser competencia de los juzgados; con lo que no existe un exceso sobre la función interpretativa porque no tendría sentido que en unos asuntos competencia ahora de los juzgados cupiera la casación y en otros no —así, M. A. RuIz LóPEZ (2009), «La inadmisión del recurso de casación por competencia de los juzgados: ¿hacia una doble instancia contencioso-administrativa?», REDA, 141, pág. 173-. En segundo lugar, porque nos encontramos ante un requisito objetivo, relativo al carácter recurrible o no de la resolución; y no dependiente, por lo tanto, de la conducta procesal del recurrente.

39 (2011: 44). La autora cita además el voto particular a la STC 46/2004, donde se señala que una cosa es el papel del legislador en el diseño de los requisitos de los recursos y otra el papel del Tribunal Supremo. En suma, para la autora, de este voto particular se deduce que «hay cosas que corresponden al Poder legislativo y otras al Poder judicial» (op. cit., pág. 47).

Todavía más: el artículo 89 hace referencia a la exposición de los requisitos de forma exigidos. Si son requisitos de forma, deberían ser subsanables; y, sin embargo, el TS no lo ha venido entendiendo así. El TC deja ahora una puerta abierta a la subsanación, pero parece que en atención a que el cambio de doctrina había sido sorpresivo. 
En este sentido se pronuncia el voto particular de Xiol Ríos a las SSTC 7 y 16/2015; voto particular al que se adhieren otros magistrados, que asimismo los han formulado frente a las SSTC 17 y 20/2015. En dicho voto se insiste en que no es que la exigencia en sí sea irrazonable, sino que no está en la Ley; que sólo la contempla como requisito del escrito de interposición ${ }^{40}$. En tal sentido, señala el voto particular que el auto recurrido afecta a la sustancia misma del acceso a la casación; con infracción de la doctrina del TEDH recogida en la sentencia Ucieza contra España ${ }^{41}$.

El problema se agrava además porque, aunque la jurisprudencia en este punto está dividida, hay resoluciones del TS que inadmiten un motivo casacional concreto, correctamente formulado en el escrito de interposición, cuando esa concreta infracción normativa no hubiera sido citada en el escrito de preparación; como sucede, por ejemplo, con el ATS de 7-6-2012 42 .

40 Así, en el voto particular a la STC 7/2015 se indica: «En suma, debe reconocerse que la resolución de inadmisión impugnada se funda en una "causa legalmente inexistente", cuya introducción no puede justificarse por el propósito perseguido por el Tribunal Supremo de reducir la inevitable tensión que, frente a ciertas ventajas, supone la opción legislativa de mantener en la casación contencioso-administrativa la duplicidad de escritos de iniciación del recurso de casación (preparación e interposición), frente a la opción de suprimir esta duplicidad, que fue la seguida en el orden jurisdiccional civil en la última reforma del régimen de dicho recurso realizada paralelamente (art. 477 de la Ley de enjuiciamiento civil, modificado por la Ley 37/11, de 10-10)».

${ }^{41}$ En esta sentencia, de 4-11-2014, se estima la demanda en un caso en que se había inadmitido la casación civil por no haber justificado el demandante que la cuantía superara los 150.000 euros. Cuando se inició el pleito, la summa gravaminis para acceder a la casación civil estaba en 36.000 euros. Dicha cuantía ya se había modificado en el momento de preparar la casación. Se requirió a la actora que justificara que la cuantía era de más de 150.000 euros; a lo que se contestó que la cuantía era inestimable porque el objeto del pleito era la propiedad sobre una iglesia medieval, pero que en todo caso el perito la valoraba al menos en 600.000 euros. Para el TEDH, la inadmisión fue en exceso formalista. Vid. en todo caso el voto particular.

42 Citado por BouAzZa ARIÑo (2013: 177). En todo caso, el autor resalta que en este punto la jurisprudencia no es unánime; y así cita, en sentido contrario, la STS de 22-5-2012, que, no obstante, hace hincapié en que los argumentos del escrito de interposición guardaban correlación con las citas de normas en el escrito de preparación, aunque se desarrollaban y completaban en el escrito de interposición. El ATS de 28-11-2013 se pronuncia en este último sentido: «Proyectadas estas consideraciones sobre el caso que ahora nos ocupa, la parte aquí recurrente, en el escrito de preparación del recurso de casación presentado ante la Sala de instancia, ha hecho indicación de los artículos 26, 30 y 32 de la Ley 58/03, General Tributaria, sin hacer mención de otros preceptos que se consideran vulnerados por la sentencia recurrida y que son desarrollados posteriormente en el escrito de interposición. No obstante, reexaminando la causa de inadmisión anunciada a la luz de las consideraciones efectuadas por el Abogado del Estado en su escrito de alegaciones, procede admitir el recurso en lo concerniente a las infracciones normativas no citadas y desarrolladas después en el escrito de interposición al amparo del artículo 88.1.d de la Ley Jurisdiccional toda vez que la vinculación de los artículos 191.4 del Real Decreto 1065/07, de 27-7, y 68 del Real Decreto $520 / 05$, de 13-5, con el resto del motivo es lo suficientemente sólida como para no desagregarlo en función de las únicas normas invocadas como infringidas en el escrito de preparación». Por su parte, la STS de 19-2-2015 asimismo rechaza la inadmisibilidad: «la cita de nuevos preceptos por primera vez en el escrito de interposición nace de la relevancia que le 
Está claro que el TS pretende de este modo descargarse de su exceso de trabajo. Pero con ello se pierde la oportunidad de conocer de recursos de casación que podrían tener verdadero interés a la hora de formar doctrina ${ }^{43}$. El exceso de trabajo de la Sala Tercera no se puede remediar creando requisitos legalmente inexistentes para el acceso a la casación, sino mediante reformas legales. Seguramente, no se ha querido implantar de forma generalizada el interés casacional como criterio de admisión porque no está generalizada la segunda instancia en el contencioso-administrativo ${ }^{44}$. Sin embargo, el núcleo indisponible para el legislador, dentro de la tutela judicial efectiva, radica en la primera instancia. No es constitucionalmente exigible una segunda instancia -ni tampoco la casación - en todo caso. Y la segunda instancia tampoco es la panacea: la verdadera forma de lograr un correcto funcionamiento de los tribunales del orden contencioso-administrativo, con carácter general, estriba en garantizar la adecuada formación de los magistrados en estas materias.

\section{La aplicación del nuevo criterio a los recursos ya presentados con an- terioridad a su establecimiento}

El ATS de 10-11-2011, que sigue la doctrina del auto de 10 de febrero, añade que aunque con este giro se incrementan las exigencias formales del escrito de preparación frente a sentencias de la Audiencia Nacional respecto de las indicadas en el auto de 14-10-2010, nos encontramos ante un cambio de criterio motivado y no arbitrario, además de con vocación de permanencia; y hace hincapié en que estos cambios de criterio entran dentro de la lógica de la evolución de la jurisprudencia —en igual sentido, por ejemplo, ATS de 21-11-2011—45. Y aña-

atribuye la parte recurrida, al pretender reforzar la postura que defiende sobre las facultades de la Administración para comprobar y para liquidar ejercicios no prescritos, debiendo significarse además que en el anuncio de preparación, en cuanto a la jurisprudencia, la parte se refiere a las sentencias de 2-2, 20-11 y 22-11-12 sobre comprobación de bases imponibles negativas».

43 Puede verse R. CANCIO FERNÁNDEZ (2012a), «El escaso interés por el interés casacional o cómo renunciar a la excelencia de nuestro Tribunal Supremo», Revista Aranzadi Doctrinal, 1, págs. 33 y ss.; del mismo (2012b), "La infundada estigmatización del interés casacional», Actualidad Jurídica Aranzadi, 840, pág. 2.

44 Partidario de que no exista instancia única sin posibilidad siquiera de casación es Ruiz López (2009: 173).

45 En todo caso, Rodríguez Carbajo (2011b: 10) indica que el ATS de 20-5-2011 rechazó que la doctrina del ATS de 10-2-2011 pudiera aplicarse a los recursos ya admitidos en aquel momento y sólo pendientes de sentencia. El autor - (2013), «La aplicación retroactiva de la nueva doctrina del Tribunal Supremo sobre el escrito de preparación», Actualidad Administrativa, 1, pág. 12 - indica que el ATS de 30-3-2011 consideró inaplicable esa nueva doctri- 
de que el hecho de que este cambio de criterio se haya aplicado a recursos de casación ya preparados tampoco es obstáculo, dado que nos encontraríamos ante una retroactividad de grado mínimo - asimismo, ATS de 16-5-2011, entre otros muchos-. Para el TS, si no se aceptara esta posibilidad de que el cambio de criterio afecte a recursos ya preparados o interpuestos, dichos cambios de criterio nunca tendrían virtualidad ${ }^{46}$.

Este último argumento tiene cierta lógica: el cambio de criterio debe plasmarse en la resolución de un caso, ya que la función jurisdiccional consiste en resolver los supuestos concretos que se plantean y no en elaborar normas generales - por mucho que hubiera pretendido el decaído Anteproyecto de LJCA de la primavera de 2014_ ${ }^{47}$. O, lo que es lo mismo, el cambio de criterio debe proyectarse sobre el caso concreto; y luego aplicarse en los sucesivos - de lo contrario, no tendría vocación de permanencia-. Pero algún caso debe ser el primero ${ }^{48}$.

na a los recursos de casación ya preparados. En cambio, cita los AATS de 15-3 y la STS de 139-2012, que consideran aplicable la nueva doctrina incluso a los recursos de casación ya interpuestos en aquel momento. Démonos cuenta de que la segunda resolución es ya una sentencia; es decir, se trata de una casación que inicialmente había superado la fase de admisión. A esta sentencia se formuló un voto particular, suscrito por dos magistrados, en que se indica que la nueva doctrina no se puede aplicar a escritos presentados con anterioridad y que ya hubieran superado la fase de admisión. Por cierto, en este caso la recurrente era la Administración estatal; al igual que en el resuelto por el ATS de 10-2-2011.

46 En cambio, CHINCHILla MARín, «La admisión...», cit., pág. 49, considera posible publicar primero la resolución judicial que anuncia el cambio de criterio; para exigirlo sólo con posterioridad.

47 De hecho, la STC 16/2015 afirma: «el Tribunal Europeo de Derechos Humanos ha señalado que las exigencias de seguridad jurídica y de protección de la confianza legítima de los litigantes no generan un derecho adquirido a una determinada jurisprudencia, por más que hubiera sido constante (STEDH de 18-12-08, caso Unédic contra Francia, § 74), pues la evolución de la jurisprudencia no es en sí contraria a la correcta administración de justicia, ya que lo contrario impediría cualquier cambio o mejora en la interpretación de las leyes (STEDH de 14-1-10, caso Atanasovski contra la ex República Yugoslava de Macedonia, § 38 ).

A lo anterior debemos añadir que en el sistema de civil law en que se desenvuelve la labor jurisprudencial encomendada al Tribunal Supremo español, la jurisprudencia no es, propiamente, fuente del Derecho - las sentencias no crean la norma- por lo que no son miméticamente trasladables las reglas que se proyectan sobre el régimen de aplicación de las leyes. A diferencia del sistema del common law, en el que el precedente actúa como una norma y el overruling, o cambio de precedente, innova el ordenamiento jurídico, con lo que es posible limitar la retroactividad de la decisión judicial, en el Derecho continental los tribunales no están vinculados por la regla del prospective overruling, rigiendo, por el contrario, el retrospective overruling (sin perjuicio de su excepción por disposición legal que establezca el efecto exclusivamente prospectivo de la Sentencia, como el art. 100.7 LJCA en el recurso de casación en interés de ley)».

48 Indica así el ATS de 10-11-2011: «En caso contrario, quedaría petrificada la nueva interpretación jurisprudencial a aquellos escritos de interposición de recursos que fueran presentados debidamente ante los Tribunales de Justicia a partir del momento del "anuncio" del cambio de criterio, "anuncio" a que no están obligados los órganos jurisdiccionales, tal y como tiene asentada la doctrina constitucional referida. Asimismo, hay que tener en cuenta que una resolución judicial que incorpora un cambio de criterio jurisprudencial y cuya eficacia fuese meramente prospectiva sería un mero obiter dictum, amén de que se frustraría la 
Desde mi punto de vista, tiene sentido que un cambio de criterio sustantivo afecte a demandas o recursos ya presentados. Este tipo de cambios entran dentro de lo que es la evolución del Derecho. El principio de seguridad jurídica no es absoluto, y aquí la protección de la legítima confianza no se halla en juego porque la parte se ha limitado a formular una demanda bajo determinados criterios jurisprudenciales sustantivos; si después esos criterios cambian y ello le afecta negativamente, su confianza legítima no habrá ido más allá de la presentación de una demanda con determinados argumentos, que después devienen inocuos como consecuencia del cambio de criterio. Para estos casos está la previsión del artículo 139 LJCA: improcedencia de la condena en costas por el principio de vencimiento, al existir serias dudas de Derecho - plasmadas en dicho cambio de criterio-.

La cuestión, sin embargo, deviene distinta cuando el cambio de criterio, como sucede en nuestro caso, afecta al comportamiento procesal del demandante o recurrente ${ }^{49}$; de forma que dicho cambio de criterio

finalidad del proceso porque la resolución no afectaría a las partes. El único límite temporal a que se limitan los cambios de criterio jurisprudenciales, de conformidad con la doctrina del Tribunal Constitucional, es a las situaciones jurídicas que gozan de la protección de la cosa juzgada, como no podía ser menos como garantía de salvaguardia de la tutela judicial efectiva proclamada en el artículo 24 de la Constitución Española» (FJ 4).

49 Puede verse Rodríguez CARBAJo (2013: 17), quien entiende que debió haberse aplicado esta regla jurisprudencial sólo a los recursos preparados con posterioridad al ATS de 102-2011 en tanto en cuanto, de otro modo, se está generando por vía jurisprudencial una retroactividad que por vía de modificación legal se habría considerado inadmisible. Vid. asimismo F. BLASCO GASCó (2008-2009), «Eficacia retroactiva y prospectiva del cambio de criterio jurisprudencial. Sentencia del Tribunal Supremo de 11-9-09», en Comentarios a las sentencias de unificación de doctrina: civil y mercantil, coord. M. YzouIERDo ToLsADA, Dykinson, Madrid, págs. 829 ss.

Asimismo, Bouazza ARIÑo (2013: 154 y ss.), para quien es más que cuestionable exigir requisitos sustantivos o formales no exigidos por la jurisprudencia existente al tiempo de presentarse el recurso. El autor, no obstante, cita en sentido contrario la STEDH Legrand contra Francia, de 2011, donde se afirma que no se infringe el derecho a un proceso justo por la decisión del Tribunal de casación francés, que, con base en una jurisprudencia posterior al inicio del proceso y que exigía que en la demanda ya se expresaran todas las alegaciones que la justificaran, estima la casación presentada por el demandado con base precisamente en esta jurisprudencia. El TEDH señala que, a fin de cuentas, el primer fallo, favorable a la demandante, no era firme; y añade que el cambio jurisprudencial se dio a conocer a las partes al presentarse el recurso de casación. Existe aquí una diferencia con el caso que nos ocupa, ya que en éste el cambio jurisprudencial afectaba negativamente a la parte recurrente en casación; y en el resuelto por la STEDH el cambio jurisprudencial afectaba, en cambio, negativamente a la parte recurrida en casación. Este caso, sin embargo, quizá es más grave, precisamente por afectar a los requisitos procesales de la demanda en primera instancia; aunque posiblemente esté justificado para garantizar la defensa del demandado desde el principio del proceso. En cambio, en el caso Petko Petkov contra Bulgaria, de 19-2-2013, se entiende vulnerado el derecho a un proceso justo porque, en un pleito sobre herencia, se desestimó la demanda por no haberse acompañado de inventario; exigencia ésta jurisprudencial nacida con posterioridad al inicio del pleito. Para el TEDH, nos encontramos con una exigencia imprevisible, a diferencia - dice- de lo sucedido en casos anteriores resueltos por el Tribunal; y que además imposibilitaba totalmente que el actor, debido al tiempo transcurrido, pudiera 
implica la inadmisión de una demanda o recurso presentado conforme a los criterios jurisprudenciales vigentes en el momento de su interposición. En estos casos, sí puede decirse que el cambio de criterio afecta decididamente al principio de protección de la confianza legítima, dado que la parte ha llevado a cabo un comportamiento procesal con arreglo a una determinada interpretación de las normas aplicables, mantenida al tiempo de la presentación de su escrito procesal; y, sin embargo, dicho escrito, debido al cambio de criterio, deviene procesalmente defectuoso ${ }^{50}$.

Por supuesto, esto puede suceder en relación con cualesquiera actos procesales de las partes; pero tiene mayor incidencia en los casos en que dicho cambio de criterio comporta la inadmisión de una demanda o recurso. Es cierto que, como hemos visto, el cambio de criterio debe plasmarse en la resolución de un caso concreto, ya que en caso contrario nos encontraríamos con un obiter dictum. Sin embargo, cuando el cambio de criterio afecta a la legítima confianza en el acceso al proceso o a los recursos es necesario introducir un factor de proporcionalidad; de forma que dicho cambio de criterio sólo esté justificado cuando resulte necesario y proporcionado al sacrificio a la protección de la confianza legítima proyectada sobre la tutela judicial.

En tal sentido, un cambio de criterio estaría justificado y sería proporcionado, en esas circunstancias, cuando se justificara adecuadamente la ilegalidad del criterio seguido con anterioridad por la jurisprudencia; o cuando se tratara de garantizar adecuadamente la defensa procesal de las otras partes ${ }^{51}$. En cambio, cuando nos encontremos ante dos interpretaciones razonables de la norma, el cambio de criterio que afecte ex post al derecho de acceso a los recursos - y no digamos a la jurisdicción- difícilmente será justificable en términos de proporcionalidad. Bien es verdad que la jurisprudencia del TC entiende que el canon de proporcionalidad no es exigible cuando se trata del

volver a ejercitar su pretensión. Se añade que en el caso Legrand el derecho de acceso a un tribunal no había quedado impedido - aunque finalmente en casación la demanda fuera desestimada- y sí en este caso.

50 Puede consultarse R. CANCIO FERnÁNDEZ (2005), «La irretroactividad de las normas procesales a propósito del recurso de súplica previo a la impugnación de autos: nuevo enfoque doctrinal a partir del auto del Tribunal Supremo de 25-3-04», Justicia Administrativa, 28, págs. 5 y ss., donde pone de relieve que dicho auto, ante la falta de norma transitoria en la LEC, señala que no cabe aplicar la exigencia de súplica contra todos los autos a los procesos iniciados antes de la entrada en vigor de aquélla, que había modificado el artículo 87.3 LJCA para generalizar la exigencia de dicha súplica contra autos.

51 Cosa que no sucede en nuestro caso, por mucho que se empeñen el TC y el Tribunal Supremo; ya que la defensa de las otras partes se garantiza adecuadamente en el trámite de oposición al escrito de interposición. 
derecho de acceso a los recursos —idea ésta que, como veremos, el TEDH no comparte- Sin embargo, aquella consideración es matizable cuando, como sucede en este caso, nos encontramos con una nueva interpretación que afecta a recursos ya presentados, e incide negativamente sobre su admisibilidad. ¿Qué diría el TC de una norma legal que estableciera nuevos requisitos para el acceso a los recursos, y que se aplicara con efecto retroactivo? Es verdad que por aplicación de la transitoria primera de la LJCA dejaron de ser recurribles ante el TS muchas sentencias, por haber pasado a ser competencia de los juzga$\operatorname{dos}^{52}$. Pero esto no se aplica a los recursos de casación ya preparados con anterioridad a la LJCA ni a las sentencias anteriores a ella, salvo que aún no hubiera transcurrido el plazo para preparar o interponer el recurso al tiempo de la entrada en vigor de la Ley — a menos que ya se hubiera preparado-; tal como se desprende de la transitoria tercera.

Además, una cosa es que determinadas resoluciones judiciales pasen a ser irrecurribles, lo que constituye un dato objetivo y ajeno al comportamiento procesal de los recurrentes; y otra distinta que los requisitos de los escritos procesales de las partes devengan retroactivamente más rigurosos, ya que en este segundo caso resulta afectada no sólo la seguridad jurídica, sino también su vertiente más específica de la confianza legítima: Y ello porque las partes acomodaron su comportamiento procesal a una determinada situación normativa y jurisprudencial; y a posteriori, y de forma sorpresiva, dicha situación varía y los actos procesales de las partes ya realizados dejan de tener acomodo a la misma.

Desde otro punto de vista, hemos visto que la STC 7/2015 finalmente estima el recurso de amparo, con base en que el recurrente había extremado su diligencia procesal y había presentado un escrito de adaptación de su escrito de preparación a la nueva doctrina jurisprudencial -en el mismo sentido, SSTC 17 y 20/2015, que resuelven sendos casos exactamente iguales-. Es decir, para el TC es relevante que el recurrente intentara "subsanar el defecto»; siendo éste el único cauce que tenía el demandante a la vista del cambio de doctrina. Pero esta solución, aunque resuelva la situación concreta del demandante, es totalmente insuficiente. No hay más que pensar que los afectados por el ATS de 10-2-2011, primero de la serie, no tuvieron oportunidad alguna de subsanar el supuesto defecto de su escrito de preparación; ya que sólo pudieron conocer la nueva doctrina de la Sección Primera de la Sala Tercera cuando se les dio audiencia sobre inadmisibilidad, e indudablemente

52 Vid. Ruiz LóPez (2009: 167 y ss.). 
sus alegaciones fueron desestimadas. El hecho de que en ese caso el recurrente fuera la Administración estatal no obsta a dicha conclusión ${ }^{53}$.

No sólo eso: según la jurisprudencia mayoritaria del TS, los defectos del escrito de preparación no son subsanables mediante el escrito de interposición; pero de lo que aquí debemos dudar es de que se trate de una verdadera subsanación ${ }^{54}$. No puede haber subsanación por el incumplimiento de un requisito que no se encuentra en la ley. De todas formas, esta nueva doctrina del TC deja una puerta abierta a la posibilidad de subsanar los defectos del escrito de preparación; aunque bien es cierto que el supuesto era excepcional ${ }^{55}$. En cualquier caso, si se considera viable la subsanación será porque estamos ante requisitos formales; no materiales. Y si se trata de requisitos formales habría que aplicar siempre la regla del artículo 138 LJCA —e incluso entender subsanables los defectos del escrito de preparación a la vista del escrito de interposición.

De hecho, las insuficiencias de esta doctrina se revelan en la STC $16 / 2015$, que desestima el amparo en un caso sustancialmente igual, porque aquí el recurrente no había intentado subsanar el «defecto»; cuando ese defecto era legalmente inexistente. Así, el voto particular a la misma formulado cuestiona también la aplicación retroactiva de la doctrina jurisprudencial. Considera el voto que una cosa es la evolución jurisprudencial y otra los límites a la aplicación retroactiva de las resoluciones judiciales; y ello con independencia de que nos encontremos ante un Ordenamiento basado en el precedente jurisprudencial o en otro basado en un modelo diferente, como el español; y en todo caso insis-

53 Los entes públicos, aun cuando hubieran actuado como tales, tienen derecho a la tutela judicial en su vertiente de acceso al proceso, a los recursos y a la igualdad procesal, así como en cuanto al derecho a un proceso con todas las garantías. Otra cosa es que en amparo no puedan alegar la falta de motivación o la motivación irracional de la sentencia, ya que ello convertiría al amparo en un contra-amparo. Pueden verse, por ejemplo, SSTC 58/2004, $175 / 2001$ y $173 / 2002$.

Y el problema se agrava a la vista de que, tal como expone con detalle CHINCHILLA MARíN (2011: 31 y ss.), el TS a lo largo de 2009 y 2010 había dictado numerosos autos en los que trataba de «fijar doctrina con carácter definitivo»; y, desde luego, diferente al luego plasmado en el ATS de 10-2-2011 y los que le siguen.

54 De hecho, en el voto particular de XIOL Ríos a la STC 16/2015 se indica: «tal intento estaba condenado al fracaso a tenor de la jurisprudencia del Tribunal Supremo, la cual, de manera unánime, de acuerdo con el parecer de este tribunal, ha denegado constantemente la posibilidad de que, salvo error material, las deficiencias de los escritos de preparación y de interposición del recurso de casación, salvo los casos de error material, puedan ser subsanadas una vez agotado el plazo para su presentación».

55 El voto particular considera así intrascendente el «intento de subsanación»; y añade que de la sentencia podría deducirse, frente al criterio jurisprudencial uniforme, que los defectos del escrito de preparación son subsanables. Máxime, se añade, cuando dicha subsanación haría perder la finalidad que a estos nuevos requisitos del escrito de preparación asigna el Tribunal Supremo. 
te en la idea de que lo que está vedado al legislador, como un cambio retroactivo de esta índole, no puede estarle permitido al TS ${ }^{56}$. Es más, en el voto particular formulado a la STC 7/2015 se señala que con esa alusión a la «subsanación del defecto» simplemente se elude el problema de la aplicación retroactiva del nuevo criterio $^{57}$.

\section{El discutible acomodo de la exigencia de requisitos de admisibilidad del recurso de casación creados jurisprudencialmente a la doctrina del TEDH}

El TC, desde su sentencia 37/1995, entiende que el control de amparo en el acceso a los recursos contra resoluciones judiciales sólo abarca los casos de arbitrariedad, irracionalidad o error patente; y ello porque el actor ya ha recibido una primera respuesta judicial ${ }^{58}$. Esta doctrina es reiteradísima; por ejemplo, se pueden citar las SSTC 181, 230 y 240/2001, 92 y 119/2008, 42 y 100/2009, 248/2005, 35/2011 y 130/2012. Es más, la STC 230/2001, entre otras, añade que aún más escrupuloso debe ser el TC cuando la resolución recurrida en amparo procede del TS, habida cuenta de lo que dispone el artículo $123 \mathrm{CE}^{59}$.

56 «Como defendí en aquel Voto particular, la eficacia temporal del cambio de criterio jurisprudencial debe ser templada cuando su aplicación se traduce, en la práctica, en la exigencia de un requisito procesal de carácter formal del que depende la acción o el recurso que no se entendía exigible en el momento de la presentación del escrito y no podía ser conocido por la parte, pues así lo impone el parámetro constitucional de la racionalidad de la decisión judicial y los principios de seguridad jurídica, confianza legítima, interdicción de la arbitrariedad y principio tempus regit actum, los cuales son incompatibles con una resolución de inadmisión dictada de manera imprevisible en tales circunstancias». Y añade: «En suma, creo que la resolución impugnada en amparo vulneró la exigencia de previsibilidad de la jurisprudencia en los casos en que este requisito está en directa relación con la exigencia de esta circunstancia respecto de la ley, en los términos en que este principio ha sido declarado por el Tribunal Europeo de Derechos Humanos (SSTEDH de 7-2-12, caso Alimuçaj c. Albania, $\S 150$ y § 156; y de 21-10-13, caso Del Río Prada c. España, § 93)».

57 «La eficacia retroactiva de los cambios de criterio jurisprudencial que se deduce de este principio no es absoluta, pues no puede prevalecer cuando implica el sacrificio de derechos o valores que la Constitución protege frente a la aplicación retroactiva de las normas, en aras de los principios de protección de situaciones consolidadas, de garantía de la seguridad jurídica, de proscripción de la arbitrariedad y de efectividad del principio de legalidad penal». Se concluye que se vulneran la confianza legítima y el principio de que no se puede obligar a cumplir lo que es inexigible.

58 Lo que, desde luego, no tiene sentido es que este canon de control en el acceso a los recursos se extienda también a los casos en que no ha existido resolución judicial de fondo. Puede verse la STC 65/2011, que afirma que cuando la sentencia de primera instancia es de inadmisión cabe apelación con independencia de la cuantía. Sin embargo, como señala MARTÍNEZ MoRALEs (2015: 29 y ss.), con anterioridad, la STC 59/2003 había entendido plausible la inadmisión de la apelación contra un auto de inadmisión.

59 En la STC 16/2015 se añade: «el Tribunal Europeo de Derechos Humanos ha señalado que la manera en la que se aplica el art. 6.1 del Convenio a este recurso extraordinario puede depender de particularidades derivadas de la apreciación de conjunto del proceso trami- 
Los cánones que utiliza el TEDH para controlar el ajuste al Convenio del derecho de acceso a los recursos contra resoluciones judiciales, sin embargo, son más generosos. El TEDH utiliza el canon de la proporcionalidad también en el acceso a los recursos; así, por ejemplo, en su sentencia Arribas Antón contra España, de 20-1-2015, donde alude a las decisiones que por su formalismo excesivo impiden el conocimiento de fondo del recurso ${ }^{60}$. Y ello aun reconociendo el amplio margen de apreciación del legislador estatal en la configuración del derecho de acceso a los recursos y aun en la creación de los mismos; particularmente, cuando se trata de recursos extraordinarios, como la casación, o incluso ajenos a instancias judiciales ordinarias, como el recurso de amparo.

A mi juicio, en realidad esto significa que, para el TEDH, una cosa es el papel del autor de la norma que crea un recurso contra resoluciones judiciales, que tiene un amplísimo margen de apreciación, y otra el papel del aplicador de la norma, que no puede adoptar decisiones que por su excesivo rigorismo o formalismo resulten desproporcionadas o supongan la desnaturalización misma del recurso ${ }^{61}$. Es de-

tado y del papel que desempeñe el tribunal de casación, pudiendo las condiciones de admisión de un recurso de casación ser más rigurosas que las propias de un recurso que haya de resolverse en grado de apelación (SSTEDH de 19-12-97, caso Brualla Gómez de la Torre c. España; y de 25-1-05, caso Puchol Oliver c. España).

Igualmente relevantes son las Sentencias del Tribunal de Estrasburgo recaídas en los casos Sociedad General de Aguas de Barcelona c. España, de 25-5-00; Llopis Ruiz c. España, de 7-11-03; e Ipamark c. España, de 17-2-04, que presentan en común juzgar resoluciones en las que nuestro Tribunal Supremo inadmitió recursos de casación por considerar que los recurrentes no habían justificado en sus respectivos escritos procesales que la infracción de normas estatales o comunitarias había sido relevante y determinante del fallo de la Sentencia recurrida. El Tribunal Europeo concluyó con la desestimación de las respectivas demandas, en la medida en que la interpretación que deba darse a los preceptos de la Ley reguladora de la jurisdicción contencioso-administrativa (LJCA) y a las condiciones de su aplicación era una cuestión que dependía de los jueces ordinarios, sin que en estos casos su interpretación pudiera tacharse de arbitraria o irrazonable o de que dificultase la equidad del procedimiento".

60 «La Cour a conclu à plusieurs reprises que l'application par les juridictions internes de formalités à respecter pour former un recours est susceptible de violer le droit d'accès à un tribunal. Il en est ainsi quand l'interprétation par trop formaliste de la légalité ordinaire faite par une juridiction empêche, de fait, l'examen au fond du recours exercé par l'intéressé (Beles et autres, précité, § 69, Zvolsky et Zvolská c. République tchèque, no 46129/99, § 55, CEDH 2002IX, et Ferré Gisbert c. Espagne, no 39590/05, § 28, 13-10-09)». Esta sentencia indica que en este caso no existía desproporción, considerando que las formalidades de los recursos deben conectarse con su finalidad, que es preservar la seguridad jurídica. O, lo que es lo mismo: esas formalidades no deben apreciarse con un rigorismo excesivo y desproporcionado para esta última finalidad. Lo mismo indica, por ejemplo, la STEDH Hassan Mohamed, de 129-2014, que señala que exigir el respeto a las reglas relativas a los plazos de presentación de los recursos no es desproporcionado ni excesivamente rigorista.

61 Así, STEDH Arribas Antón, antes citada, por mencionar una de las más recientes: «La Cour rappelle d'emblée que le "droit à un tribunal", dont le droit d'accès constitue un aspect, n'est pas absolu et qu'il se prête à des limitations implicitement admises, notamment en ce qui concerne les conditions de recevabilité d'un recours, car il appelle de par sa nature même une 
cir, la doctrina del TEDH y la del TC coinciden en la consideración del derecho de acceso a los recursos como de configuración legal; pero a partir de ahí son divergentes, ya que para el TC el derecho de acceso a un recurso se satisface si la decisión de inadmisión no es manifiestamente irrazonable, arbitraria o incursa en error patente, mientras que para el TEDH no basta que la decisión de inadmisión respete estos parámetros, sino que además es preciso que no resulte desproporcionada a la finalidad perseguida por la norma que establece las formalidades necesarias para el acceso al recurso — esencialmente, garantizar la seguridad jurídica y los derechos de defensa de las otras partes-. Canon éste que se aproxima mucho al utilizado por el TC para controlar el derecho de acceso a la jurisdicción.

De hecho, como es sabido, el TEDH, en sentencias Sáez Maeso contra España ${ }^{62}$ y Salt Hiper contra España, ha considerado contraria al artículo 6 del Convenio la inadmisión de un recurso de casación, tras haber sido admitido previamente a trámite por el TS o considerado como bien preparado, cuando ha transcurrido largo tiempo desde la admisión inicial hasta la sentencia de inadmisión - en el caso Salt Hiper, además, habiendo mediado una previa estimación de un recurso de queja-; si bien es cierto que se utilizó asimismo el argumento de que, bajo la Ley 10/1992, no era precisa la audiencia de las partes con anterioridad a la inadmisión de la casación ${ }^{63}$.

Estas sentencias son relevantes; porque lo que se viene a decir es que resulta contradictorio tener por bien preparado un recurso de casación y después inadmitirlo en sentencia, aunque bien es cierto que existían en ese caso las dos circunstancias cualificadas mencionadas

réglementation par l'État, lequel jouit à cet égard d'une certaine marge d'appréciation (García Manibardo c. Espagne, no 38695/97, § 36, CEDH 2000-II, et Mortier c. France, no 42195/98, § 33, 31-7-01). Néanmoins, les limitations appliquées ne doivent pas restreindre l'accès ouvert à l'individu d'une manière ou à un point tels que ce droit s'en trouve atteint dans sa substance même. En outre, elles ne se concilient avec l'article $6 \S 1$ de la Convention que si elles poursuivent un but légitime et s'il existe un rapport raisonnable de proportionnalité entre les moyens employés et le but visé (Guérin c. France, 29-7-98, § 37, Recueil des arrêts et décisions 1998-V, et Beles et autres c. République tchèque, no 47273/99, § 61, CEDH 2002IX)».

62 Esta sentencia dio lugar a un cambio en la doctrina del TC: puede verse STC 248/2005.

63 Vid. R. M. Martín-Romo Capilla (2005), «El recurso de casación contencioso-administrativo: su inadmisión en sentencia y la previa audiencia a las partes», REDA, 125, págs. 164 y ss. Sobre esta jurisprudencia, asimismo, O. BouAzZa ARIÑo (2012), "Recurso de casación contencioso-administrativo común y derecho a la tutela judicial efectiva (estudio de las SSTEDH Sáez Maeso C. España, de 9-11-04, Salt Hiper S.A. C. España, de 7-6-07 y Llavador Carretero C. España, de 15-12-09)», en Administración y justicia: un análisis jurisprudencial: liber amicorum Tomás-Ramón Fernández, coords. E. GARCÍA DE ENTERRÍA y R. AlONSO GARcía, vol. 2, págs. 2735 y ss. Desde otra perspectiva, M. J. Alonso MAs (2013), «Recurso de casación en el orden contencioso-administrativo y Derecho autonómico», Revista de Administración Pública, 190, págs. 116 y ss. 
- transcurso de un largo tiempo y omisión de audiencia de las partes-. Es decir, resulta cuestionable que se tenga por bien preparado un recurso de casación y que después se inadmita el mismo por defectuosa preparación. Y máxime cuando la defectuosa preparación es el resultado de una interpretación ex novo de los requisitos de acceso a los recursos, que en realidad va más allá de la mera interpretación para convertirse en creación de nuevos requisitos. Si es la seguridad jurídica la razón por la que el legislador regula los requisitos formales de los recursos, dicha seguridad jurídica se compatibiliza mal con la creación de nuevos requisitos formales por vía jurisprudencial; máxime cuando no existe unanimidad en la Sala Tercera en este punto.

En cualquier caso, que el TEDH considere irregular la existencia de contradicciones entre la resolución que tiene por preparada la casación y la resolución de inadmisión puede ser un argumento más para reconsiderar, lege ferenda, la conveniencia de mantener el trámite de preparación del recurso de casación. $\mathrm{O}$, al menos, cabría cuestionar la conveniencia de modificar el artículo 93.2 LJCA, que permite la inadmisión de la casación por defectuosa preparación, aunque inicialmente el recurso se hubiera tenido por correctamente preparado.

Es más: existen sentencias del TEDH que conectan los requisitos formales del recurso de casación con las especiales exigencias del control casacional. Por ejemplo, en el caso Barrenechea Atucha se estima la demanda porque no quedaba impedido el control casacional del $\mathrm{TS}^{64}$. También en la sentencia Golf Extremadura se llega a la misma conclusión; en ese caso, en el escrito de preparación se habían invocado normas estatales, y el TEDH no da importancia al hecho de que las

\footnotetext{
${ }^{64}$ La inadmisión de la casación se había basado en que el escrito de preparación no habría justificado suficientemente la relevancia y carácter determinante del Derecho estatal o europeo. Pero el TEDH señala que en dicho escrito sí se había invocado el Derecho estatal, señalando que en la sentencia de instancia esas normas estatales habían sido aplicadas; y el recurrente, añade el TEDH, se quejaba de la defectuosa aplicación de dichas normas. Todo ello se considera suficiente para ejercer el control casacional.

También la STEDH Llavador Carretero estima la demanda por considerar excesivamente formalista la posición del TS y del TC; el primero había entendido que el escrito de preparación estaba insuficientemente fundamentado desde la perspectiva del Derecho estatal y europeo. Y ello pese a que en la STEDH Ipamark, por ejemplo, se había afirmado que en principio las condiciones de la admisión de la casación se deben apreciar por los tribunales internos; y que en la sentencia Barrenechea se indicaba que el carácter formalista de la casación puede implicar unas condiciones de admisión más severas que en la apelación.

Tengamos en cuenta que hasta ahora las sentencias estimatorias del TEDH se han pronunciado sobre casos en que se recurrían en casación sentencias de los TSJ; y donde la inadmisión se había pretendido fundamentar en la falta de justificación del juicio de relevancia en el escrito de preparación. El caso aquí comentado es incluso más flagrante, dado que se trata de la inadmisión de la casación contra una sentencia de la Audiencia Nacional, donde ningún juicio de relevancia hay que justificar en el escrito de preparación.
} 
mismas no hubieran sido citadas por la sentencia recurrida en casación ${ }^{65}$.

Es decir, la configuración de los requisitos formales en el acceso a la casación tiene por finalidad preservar la función del recurso de casación y el control casacional. Siendo así, no se entiende en qué medida la adición de nuevos requisitos para el trámite de preparación puede ser necesaria para dicha finalidad; máxime si después el recurrente tiene que formular su escrito de interposición. Es decir, si se quiere mantener la dualidad preparación-interposición, cada uno de estos escritos debe tener su propia finalidad; sin que sea necesario que la preparación ya sea una pre-interposición. Esa exigencia duplicada resulta desproporcionada, por innecesaria. De hecho, en la sentencia $\mathrm{Ba}$ rrenechea se señala — en un caso en que era preciso el juicio de relevancia ya desde el escrito de preparación- que sí se había citado Derecho estatal en dicho primer escrito; de donde se puede deducir que en estos casos basta con la cita del Derecho estatal, sin necesidad de mayor argumentación. Y ello en un caso en que lo recurrido era una sentencia de un Tribunal Superior de Justicia.

Y, por lo demás, si lo importante es que la actuación procesal del recurrente sea suficiente para permitir el control casacional, mientras el legislador siga manteniendo la dualidad entre preparación e interposición, al menos habría que entender que los posibles «defectos de contenido» del escrito de preparación deberían entenderse subsanables cuando el contenido del escrito de interposición fuera correcto, al haberse articulado adecuadamente los motivos casacionales. En este punto, sin embargo, como hemos visto, la jurisprudencia del TS apunta en sentido contrario. Es más, cuando se sigue la línea más formalista, la exigencia de cita de los preceptos y jurisprudencia que se consideran infringidos por la sentencia de la Audiencia Nacional ya en el escrito de preparación impide, además, dar entrada en el escrito de interposición a nuevas posibles infracciones legales o a la doctrina jurisprudencial. Y esto es especialmente grave si tenemos en cuenta el breve plazo de presentación del escrito de preparación, diez días; frente a los treinta días para formular el escrito de interposición ${ }^{66}$.

65 En el caso Sáez Maeso contra España, asimismo, se considera lesionado el derecho a un proceso justo, en un caso en que se había incurrido en error en la incardinación del concreto motivo casacional en el escrito de interposición. El recurso fue inicialmente admitido a trámite pero inadmitido en sentencia siete años después, como hemos visto. Para el TEDH, en estas circunstancias no se podía tachar de negligente la actuación procesal del recurrente.

66 De hecho, así se argumentaba en el amparo resuelto por STC 16/2015, donde los recurrentes aducían, entre otras cosas, que se había procedido a una indebida refundición de los escritos de preparación e interposición; cuando son escritos diferentes y con plazos distintos. 


\section{CONCLUSIONES}

A mi juicio, en los supuestos en que se ha planteado el amparo por inadmisión de un recurso de casación con base en la doctrina del ATS de 10-2-2011, el pronunciamiento del TC debería haber sido estimatorio. Lo relevante no era que en algunos de los casos el recurrente hubiera intentado la «subsanación del defecto», sino que el escrito de preparación no era defectuoso porque el TS no puede exigir requisitos que no se encuentran en la ley. En este caso — como también en aquellos previos autos en que se exigía ya en el escrito de preparación la expresión del concreto motivo casacional-, el TS se ha extralimitado en su función interpretativa y se ha colocado en un lugar que le corresponde al legislador. Si el derecho de acceso a los recursos es de configuración legal hay que estar al diseño del recurso, y de sus requisitos, que indique el legislador; sin que por vía jurisprudencial se puedan añadir otros nuevos. La determinación de los motivos del recurso, y de los preceptos y jurisprudencia infringidos, es función del escrito de interposición, conforme al artículo 92 LJCA; no del escrito de preparación.

Incluso desde la perspectiva de la proporcionalidad, que para el TEDH asimismo debe valorarse en el acceso a los recursos contra resoluciones judiciales, se puede cuestionar la doctrina del TC y, por supuesto, la del TS: porque no resulta necesaria, y por tanto es desproporcionada, la exigencia de un doble trámite, de preparación y luego de interposición-admisión, cuando en realidad el primero se convierte en una anticipación del segundo por la desmesurada ampliación de sus contenidos efectuada por vía jurisprudencial. Es más, cabe cuestionar que el Tribunal a quo, o, mejor dicho, el Secretario judicial del Tribunal a quo — que es quien en principio da por bien preparada la casación; y que sólo en caso de duda o de evaluación negativa defiere la decisión a la Sala-, pueda controlar una cuestión cuyo enjuiciamiento a la postre compete al TS, como es la cita de los preceptos legales y de la jurisprudencia que se estiman infringidos. Esto se refuerza a la vista del artículo 93 LJCA, que ya no encomienda al Secretario judicial, sino a la Sección correspondiente, no sólo la inadmisión del recurso de casación, sino también su admisión; a la vista del escrito de interposición.

La aplicación de esa doctrina a recursos ya preparados con anterioridad a que se hiciera público el ATS de 10-2-2011 vulnera asimismo la confianza legítima; ya que se añade un nuevo requisito, retroactivamente y por vía jurisprudencial, que afecta al comportamiento procesal de las partes. 
Otra cosa es que, hoy por hoy, para que la Sala Tercera cumpla con su función adecuadamente sea necesario cambiar el sistema de acceso a la casación. Que la Sala Tercera no esté cumpliendo con su función se evidencia incluso si analizamos la evolución jurisprudencial sobre la interpretación de los requisitos de acceso a la casación; donde ha habido tendencias jurisprudenciales encontradas, cada una de las cuales ha pretendido "clarificar definitivamente» el criterio. El asentamiento - equivocado, desde mi punto de vista- de la doctrina del TS en este punto se ha producido más de doce años tras la entrada en vigor de la LJCA. Aunque al final la conclusión del TC ha sido la inexistencia de infracción de la igualdad en la aplicación de la ley, por no poderse hablar de resoluciones ad personam, sin embargo, las vacilaciones jurisprudenciales, puestas de relieve por el Ministerio Fiscal y por los recurrentes en amparo, evidencian los problemas que tiene la Sala Tercera para cumplir adecuadamente con su función de unificación de doctrina.

Posiblemente, lo más adecuado, para preservar las funciones del TS como órgano de unificación de doctrina y como garante de la defensa objetiva del Ordenamiento, sea instaurar el interés casacional, no como criterio negativo de inadmisión en determinados casos, sino como criterio general de admisión; de forma que además competa exclusivamente al TS determinar cuándo concurre el interés casacional. Es decir, que la Sala Tercera sólo deba motivar cuando admita el recurso por concurrir el interés casacional; y no a la inversa, de modo parecido al sistema establecido para el amparo por la LO 6/2007 y refrendado recientemente por la STEDH Arribas Antón. Pero se trata de una decisión que corresponde al legislador; sin que el TS pueda sustituir a éste en el diseño del recurso de casación. 
